\title{
Wind Resource Assessment and Wind Energy System Cost Analysis: Fort Huachuca, Arizona
}

Timothy L. Olsen

Tim Olsen Consulting

Denver, Colorado

Ed McKenna

National Renewable Energy Laboratory Golden, Colorado

NREL technical monitor: Ed McKenna
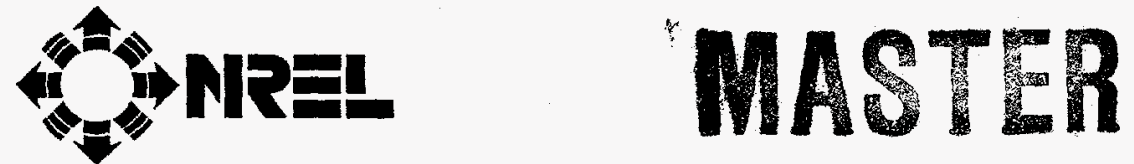

National Renewable Energy Laboratory 1617 Cole Boulevard

Golden, Colorado 80401-3393

A national laboratory of the U.S. Department of Energy Managed by Midwest Research Institute for the U.S. Department of Energy under contract No. DE-AC36-83CH10093

Work performed under Subcontract No. CAK-6-15387-01

December 1997

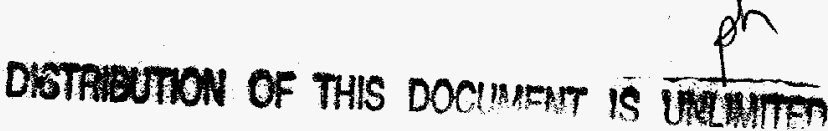




\section{NOTICE}

This report was prepared as an account of work sponsored by an agency of the United States government. Neither the United States government nor any agency thereof, nor any of their employees, makes any warranty, express or implied, or assumes any legal liability or responsibility for the accuracy, completeness, or usefulness of any information, apparatus, product, or process disclosed, or represents that its use would not infringe privately owned rights. Reference herein to any specific commercial product, process, or service by trade name, trademark, manufacturer, or otherwise does not necessarily constitute or imply its endorsement, recommendation, or favoring by the United States govemment or any agency thereof. The views and opinions of authors expressed herein do not necessarily state or reflect those of the United States government or any agency thereof.

Available to DCE and DOE contractors from:

Office of Scientific and Technical Information (OSTI)

P.O. Box 62

Oak Ridge, TN 37831

Prices available by calling (423) $576-8401$

Available to the public from:

National Technical Information Service (NTIS)

U.S. Department of Commerce

5285 Port Royal Road

Springfiald, VA 22161

(703) $487-4650$ 


\section{DISCLAMERR}

Portions of this docoment may be illegible in electronic imsge produets. Images are produced from the best available origion doerment 


\section{CONTENTS}

$\underline{\text { Page }}$

Foreword iv

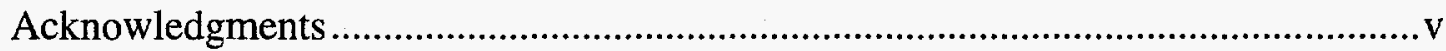

Executive Summary ..................................................................................

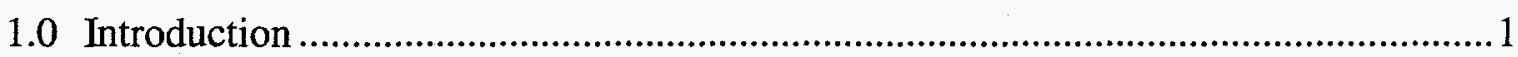

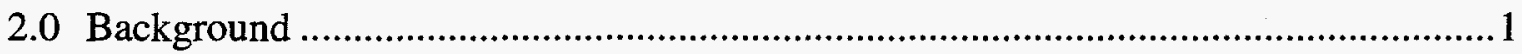

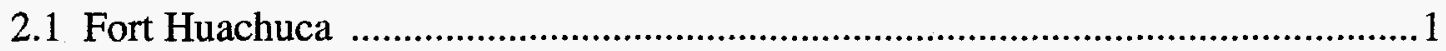

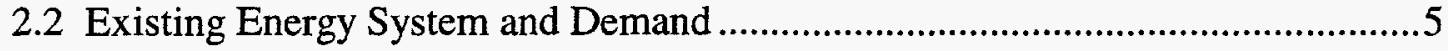

2.3 Wind Measurement Site Descriptions...........................................................

2.4 Wind Data Collection and Analysis ..........................................................

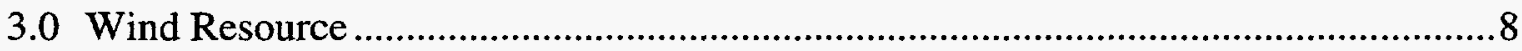

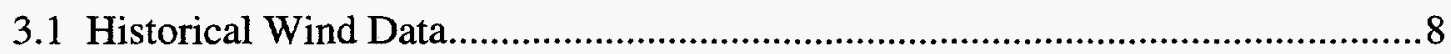

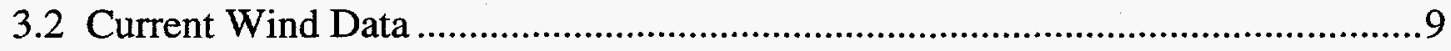

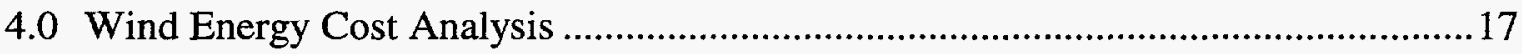

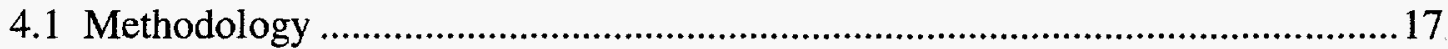

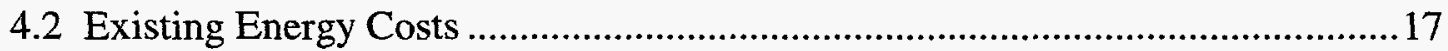

4.3 Wind Generation System ......................................................................... 18

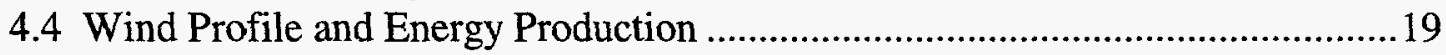

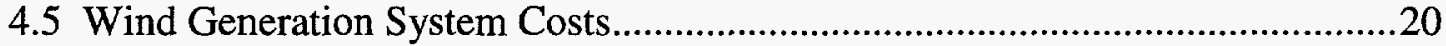

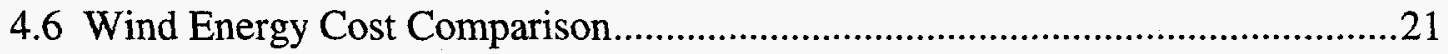

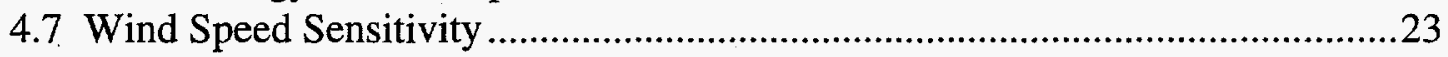

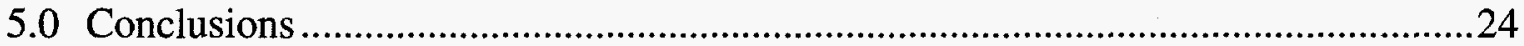

References

Appendix: Economic Summary Tables 


\section{LIST OF TABLES}

$\underline{\text { Page }}$

1. Summary of Current Fort Huachuca Meteorological Data ...............................10

2. Balance of Station Costs for Eight $225 \mathrm{~kW}$ Wind Turbines.............................20

3. 1996 Wind Energy System Economics .....................................................22

4. Economic Sensitivity to Wind Speed Variations ..............................................23

\section{LIST OF FIGURES}

Page

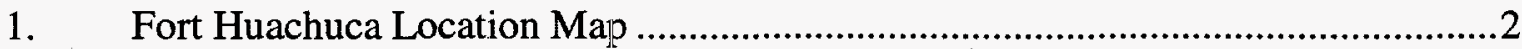

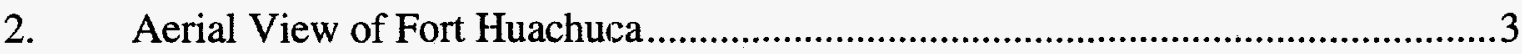

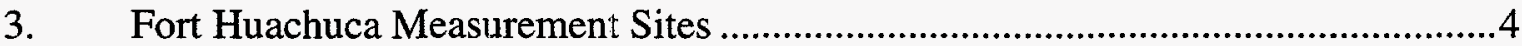

4. Fort Huachuca Monthly Energy Consumption ...........................................5

5. Fort Huachuca Monthly Peak Demand ..................................................... 6

6. Fort Huachuca Monthly Cost of Energy ......................................................

7. Fort Huachuca Monthly Power Factor ........................................................

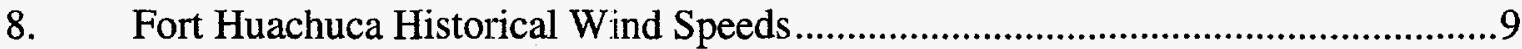

9. Fort Huachuca Wind Speed Frequency Distribution ................................... 11

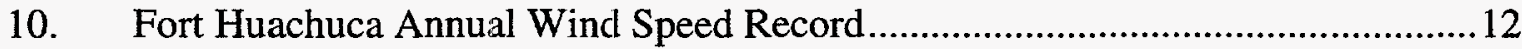

11. Fort Huachuca Annual Average Diurnal Wind Speed.....................................13

12. Other Fort Huachuca West Gate DCP2 Annual Average Data ..........................15

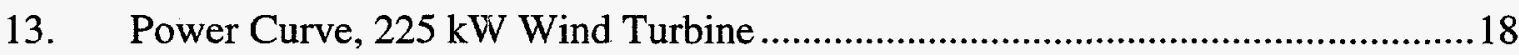

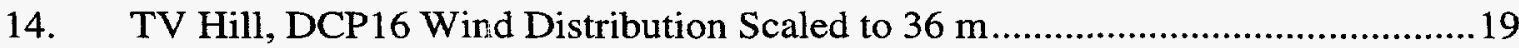




\section{FOREWORD}

This report was prepared as an account of work for others funding contract, sponsored by the Department of Defense (DoD) Strategic Environmental Research and Development Program (SERDP) under Department of Energy (DOE) Contract \# DE-AC02-83CH10093.

The objective of this joint DOE and National Renewable Energy Laboratory (NREL) SERDP project is to determine whether wind turbines can reduce costs by providing power to US military facilities in high wind areas. In support of this objective, one year of data on the wind resources at several Fort Huachuca sites was collected. The wind resource data were analyzed and used as input to an economic study for a wind energy installation at Fort Huachuca. The results of this wind energy feasibility study are presented here.

Timothy $\mathrm{L}$. Olsen, an engineering consultant, was contracted by NREL to provide data reduction analysis, research historical wind resource data, perform wind energy economic analysis, and generate this report.

\section{ACKNOWLEDGMENTS}

The authors wish to acknowledge major contributions to the success of this project by Art Trapp and the Fort Huachuca meteorological team, who installed, commissioned, and operated the meteorological test equipment. Neil Kelley of NREL shared his meteorological advice and guidance in presentation and interpretation of the wind resource data. Bill Stein, the Fort Huachuca Energy Manager, advised on all aspects of Fort Huachuca facilities, operations and costs. Bill Stein and Art Trapp made the site available for study and arranged travel to and from Fort Huachuca. Roni Olsen of Highline Editions developed and refined the numerous graphs in the report. Each of these people deserves special thanks for their role in bringing this project together. 


\section{EXECUTIVE SUMMARY}

This report presents the results of meteorological testing at three different sites on Fort Huachuca, followed by an economic assessment of a small wind energy project at the best site.

Fort Huachuca has a marginal wind resource, with annual average wind speeds of 3.9 to $5.1 \mathrm{~m} / \mathrm{s}$

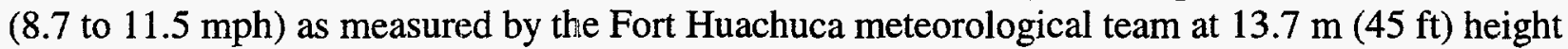
at three collection sites on the base between 1 July 1995 and 30 June 1996. Somewhat helpful, though, are strong positive vertical wind shears, which could scale wind speeds up to $7.0 \mathrm{~m} / \mathrm{s}$ $(15.7 \mathrm{mph})$ at a wind turbine hub height of $36 \mathrm{~m}(118 \mathrm{ft})$ with 0.35 scaling coefficient.

A wind energy system was evaluated to examine the merits of supplementing grid energy with eight $225 \mathrm{~kW}$ wind turbines. Using conservative assumptions (unfavorable to wind energy) throughout the analysis, the wind energy system displayed marginal economics. The levelized cost of energy for the wind and grid energy case using eight $225 \mathrm{~kW}$ wind turbines is $\$ 0.100 / \mathrm{kWh}$, nearly unchanged from the baseline case without wind $(\$ 0.101 / \mathrm{kWh})$. The payback period is 14.3 years, the internal rate of return $5.7 \%$.

More substantial benefits of wind energy would require a site with stronger winds or lower equipment prices, perhaps from the used-turbine market. Tall towers may present another means of gaining favorable wind economics, provided the high wind shears can be verified at higher measurement levels. 


\subsection{INTRODUCTION}

This report analyzes the local wind resource and evaluates the costs and benefits of supplementing the current purchased grid energy at Fort Huachuca, Arizona with wind turbines. In Section 2.0 the Fort Huachuca site, operations, and current energy system are described, as are the data collection and analysis procedures. Section 3.0 summarizes the measured wind resource data and analyses. Section 4.0 presents the conceptual design and cost analysis of a wind energy system at Fort Huachuca, with conclusions following in Section 5.0. Appendix A presents summary sheets from the economics spreadsheet model.

\subsection{BACKGROUND}

\subsection{Fort Huachuca}

Fort Huachuca is a United States Army fort with a variety of divisions and functions, the foremost being the US Army Intelligence Center and School. It also includes the US Army Signal Command, the US Army Eleventh Signal Brigade, the US Army Electronic Proving Ground, the Department of Defense Joint Interoperability Test Command, Arizona Army National Guard, Army Reserve, the Missouri Air Guard, and an air field shared by the Sierra Vista airport and A10's and fighter jets from Davis Monthan Air Force Base in Tucson. As shown in Figure 1, the fort is located in southeast Arizona, approximately sixty miles southeast of Tucson. Fort Huachuca is situated just east of the Huachuca Mountains, at latitude $31.4 \mathrm{~N}$, longitude 110.2W and elevation $1423 \mathrm{~m}(4667 \mathrm{ft})$. The base is approximately 15 miles east to west, 11 miles north to south, minus a southeast corner, and encompasses an area of 114 square miles of land owned by the US Army.

The base, with scattered trees, slopes down gently to the northeast in the developed eastern portion, with rugged mountains to the west. With 2100 to $2300 \mathrm{~m}$ (7000 to $7500 \mathrm{ft}$ ) ridgelines and a peak at $2560 \mathrm{~m}(8400 \mathrm{ft})$, the Huachuca mountains may have significant weather interaction with

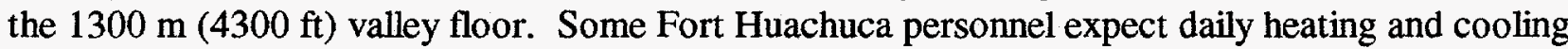
drainage wind flows to amplify in several of the large canyons. An aerial photograph of the base is shown in Figure 2.

In general, daily maximum temperatures vary from 4 to $38 \mathrm{C}(40$ to $100 \mathrm{~F})$, and daily minimum temperatures vary from -9 to $24 \mathrm{C}(15$ to $75 \mathrm{~F})$. The coolest months are December and January, and the warmest months are June and July. The lowest temperature recorded at Fort Huachuca between 1961 and 1990 is $-13 \mathrm{C}(9 \mathrm{~F})$, the highest $40 \mathrm{C}(104 \mathrm{~F})$. Precipitation averages $0.38 \mathrm{~m}$ (14.8 in) per year; snowfall averages $0.22 \mathrm{~m}$ ( $8.7 \mathrm{in})$ per year. Most of the rain falls from July through September. The relative humidity ranges from $7 \%$ to $97 \%$, with an average of $28 \%$.

Winds at Fort Huachuca primarily blow from the West and are stronger in spring. Average wind

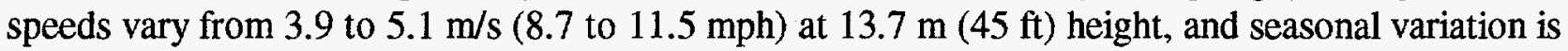
small. The windiest months, March through May, have wind speeds averaging 5 to $6 \mathrm{~m} / \mathrm{s}$. The least windy months, July through December, have wind speeds averaging 3 to $4 \mathrm{~m} / \mathrm{s}$. 
Fort Huachuca is a complete community which houses 8700 people and has a working population of 15,800 . The base includes a 30 bed hospital, library, schools for 1680 students, golf course, airfield with $3660 \mathrm{~m}(12,000 \mathrm{ft})$ runway, several government and private businesses and an assortment of military facilities for electronic warfare training, testing, and general operations. A map of the base including measurement sites appears in Figure 3.

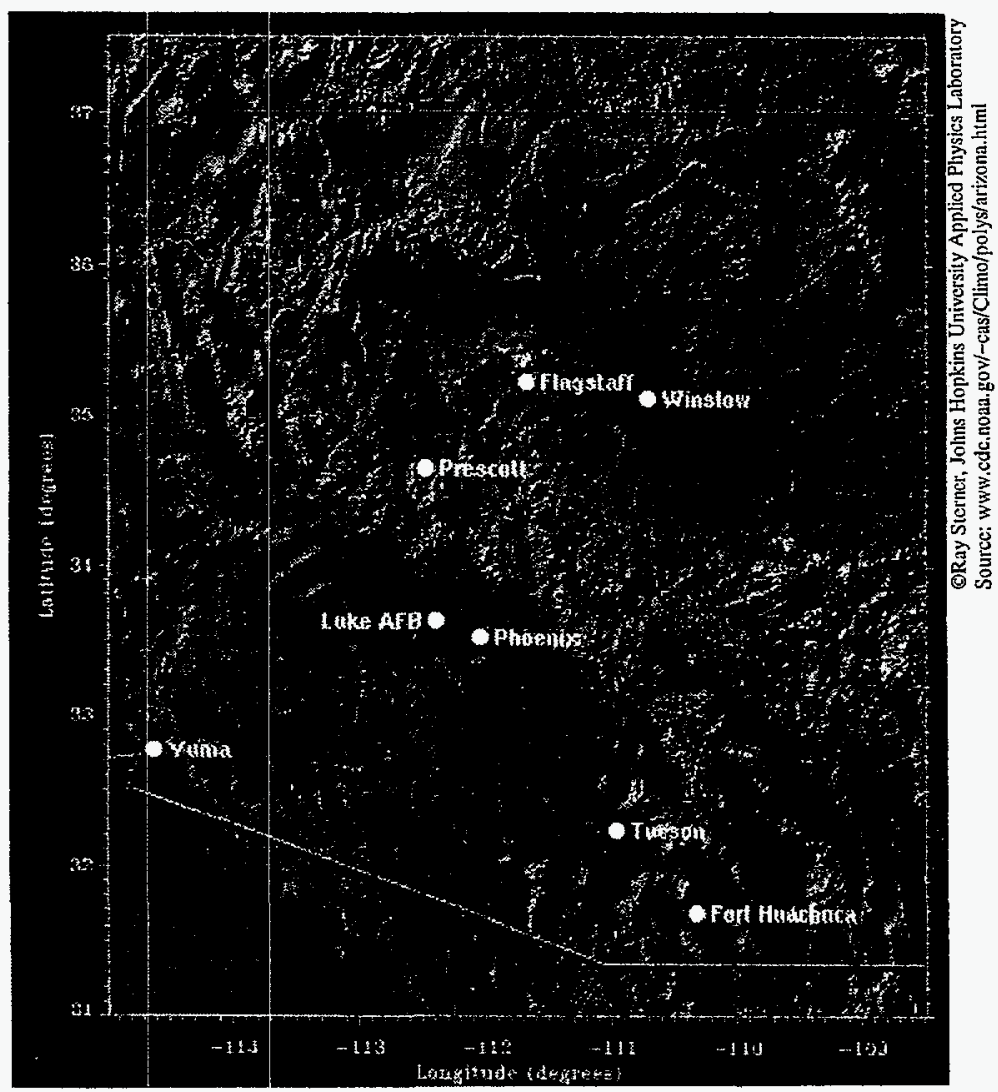

Figure 1: Fort Huachuca Location Map 




Figure 2: Aerial View of Fort Huachuca 


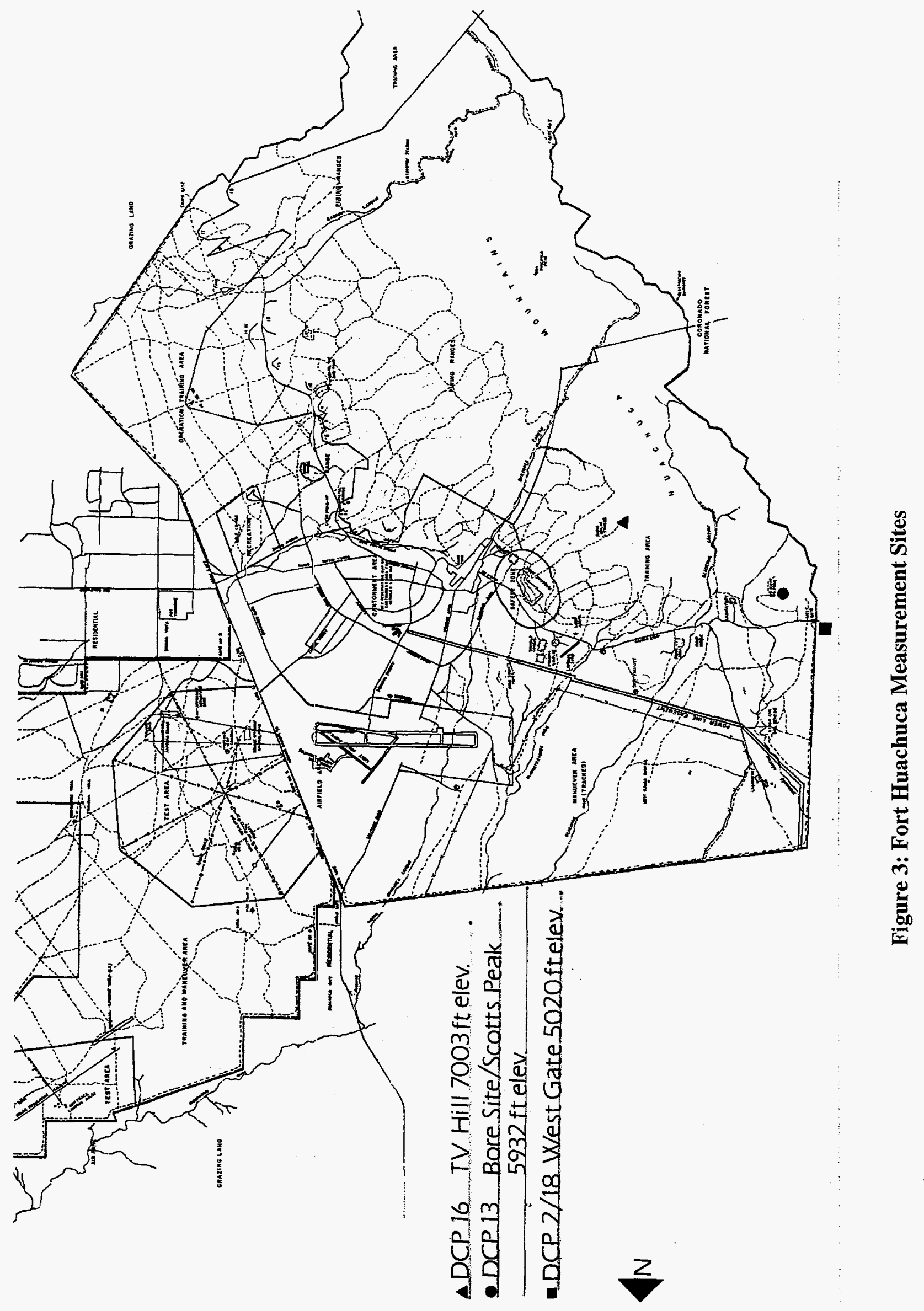




\subsection{Existing Energy System and Demand}

Fort Huachuca consumes approximately 9 million $\mathrm{kWh}$ per month at a cost near $\$ 0.07 / \mathrm{kWh}$ for a monthly bill of $\$ 630,000$. Electric power at Fort Huachuca is supplied by Tucson Electric Power (TEP) through their grid. Figures 4 through 7 show the monthly energy consumption, peak demand, cost of energy (based on TEP charges), and power factor. The annual demand cycle peaks in summer time as expected in a hot climate. Cost of energy rose significantly in the late eighties, but nearly leveled off in the nineties. Power factor improvements give some reduction in energy costs.

The Fort Huachuca Energy Manager has been conducting ongoing base resource use improvements, both for energy and water. The energy improvements include a variety of efficiency measures and supplemental and experimental renewable energy systems: solar water heating, solar photovoltaics, and solar thermal Stirling engine electricity generation. A $30 \mathrm{~kW}$ photovoltaic array and inverter bank are operating on the thrift shop near the main gate. The solar thermal system consists of an array of mirrors focused on a $11 \mathrm{~kW}$ Stirling engine. Currently, wind generation is under study.

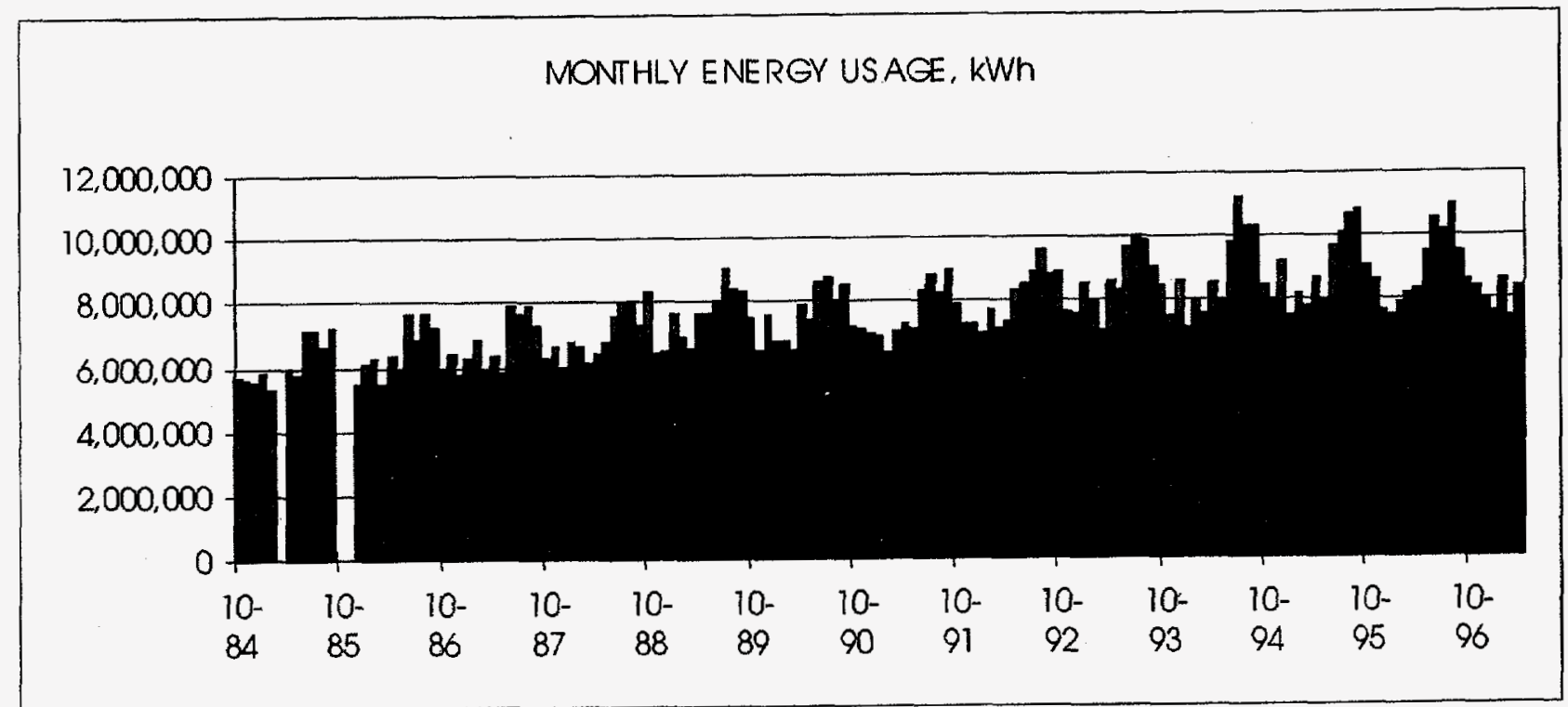

Figure 4: Fort Huachuca Monthly Energy Consumption 


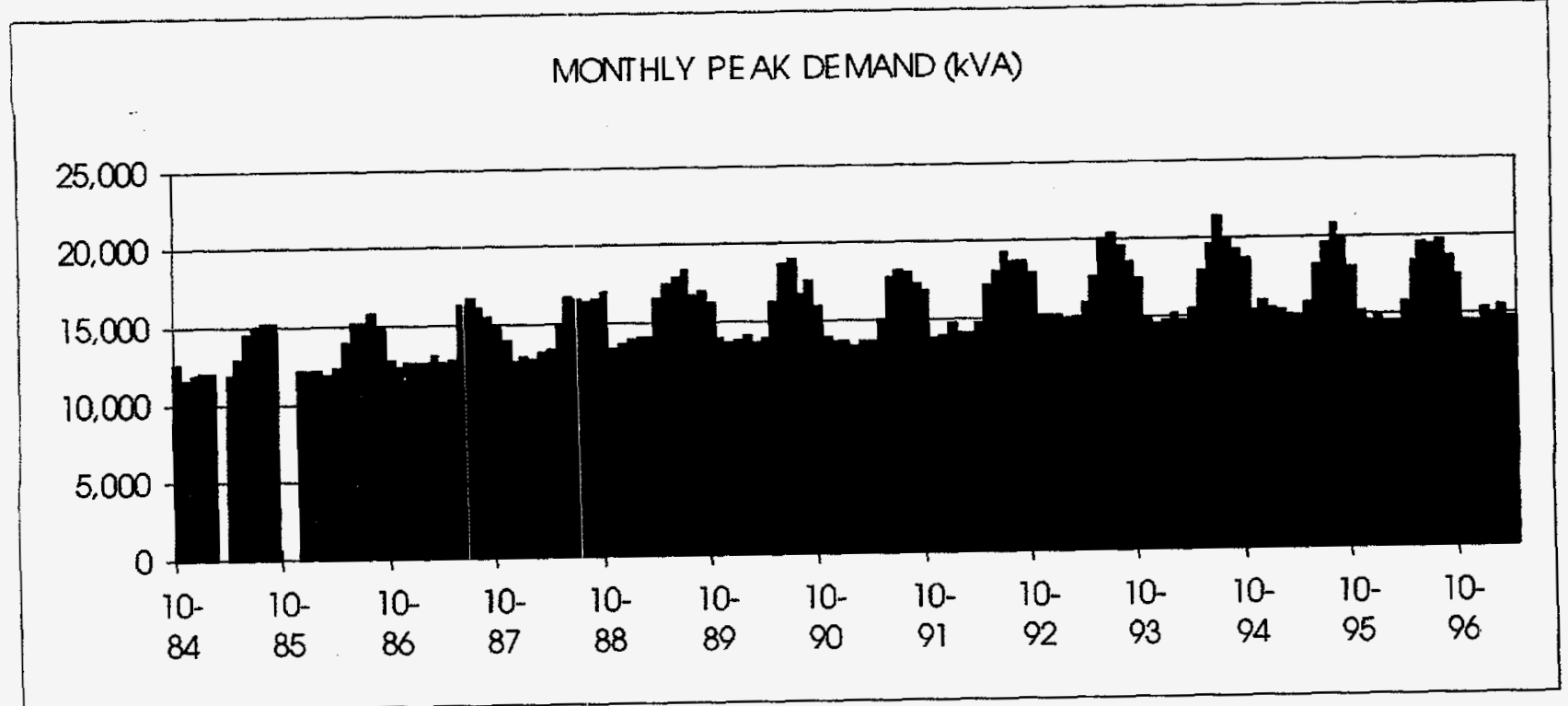

Figure 5: Fort Huachuca Monthly Peak Demand

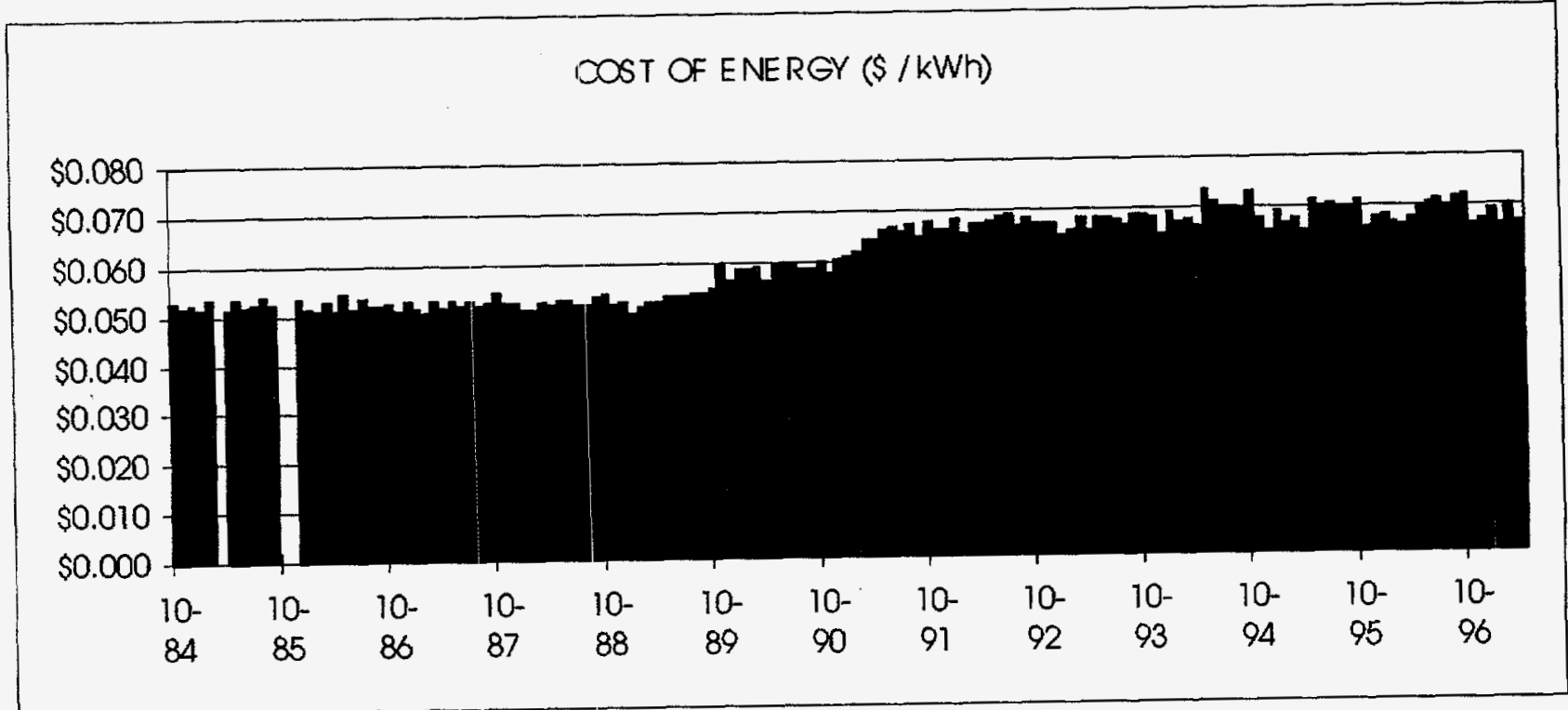

Figure 6: Fort Huachuca Monthly Cost of Energy 


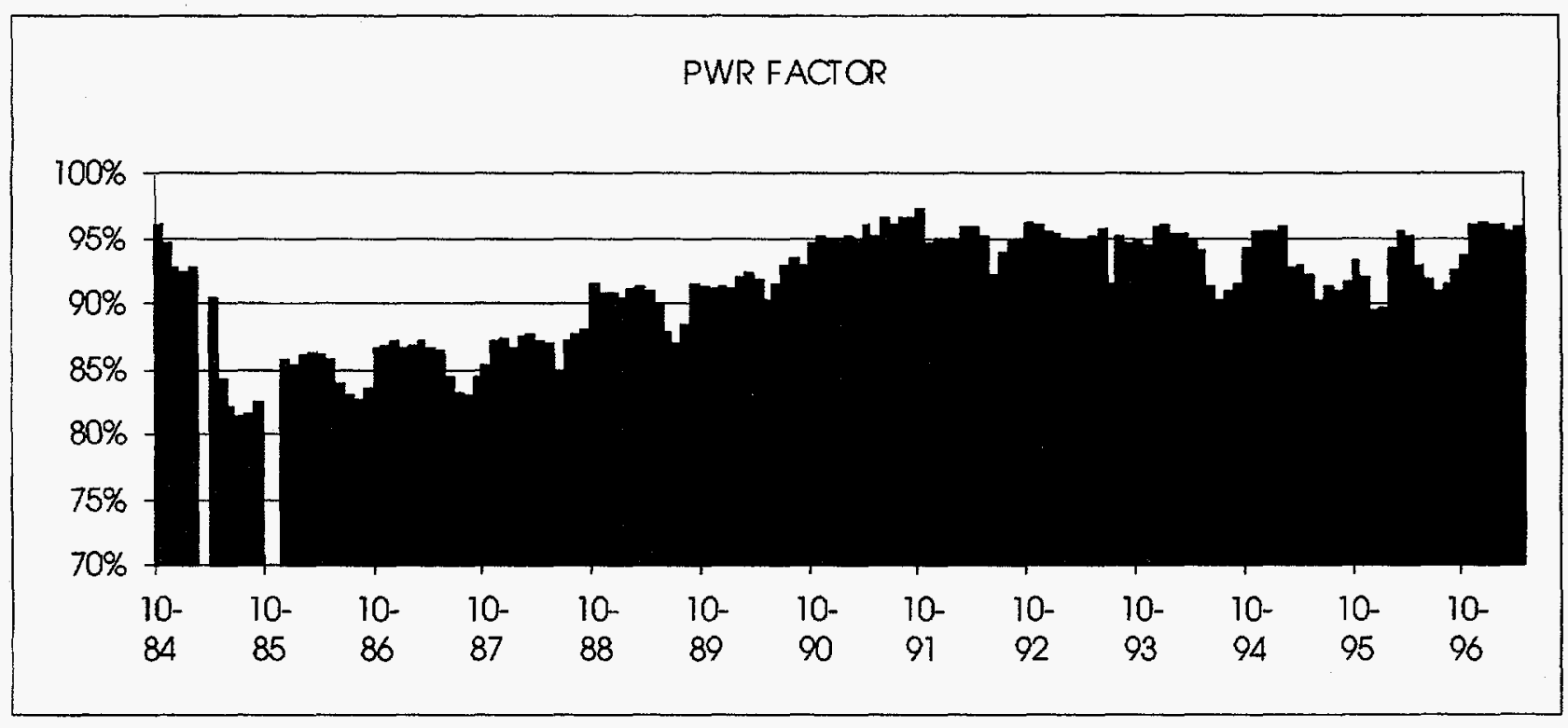

Figure 7: Fort Huachuca Monthly Power Factor

\subsection{Wind Measurement Site Descriptions}

Three sites have been monitored at Fort Huachuca: Data Collection Points (DCP) 2, 13, and 16. A separate data set labeled DCP 18 contains an extra level of $(30.5 \mathrm{~m} ; 100 \mathrm{ft})$ data at DCP 2 . Shown in Figure 3, their locations are:

DCP 2/18: "West Gate," elevation $1530 \mathrm{~m}$ (5020 ft), toward the northwest end of the base and the north end of the Huachuca Mountains with possible influence from, but not in direct alignment with, Blacktail Canyon.

DCP 13: "Bore Site," elevation $1814 \mathrm{~m}$ (5952 ft), a topographically complex site near Scott Peak and near the northwest edge of the Huachuca Mountains.

DCP 16: "TV Hill," elevation $2135 \mathrm{~m}$ (7003 ft), a peak near the center of the Huachuca Mountains between the south and west Fort Huachuca base ranges and southeast of Bore Site.

These sites are either southeast or northwest of the base buildings by a half mile or more. They are on the edge of the valley floor, which has scattered low trees. The trees thicken in the rugged mountains to the southwest.

These sites all have mild to moderate winds, with marginal energy production potential. Stronger wind may exist along the ridgelines, but accessibility is severely limited. Some local terrain-induced wind amplification could be found with sufficient prospecting. Fort Huachuca staff view the 
canyons as likely amplification sites, but acknowledge potential problems with space and protected bat territory.

\subsection{Wind Data Collection and Analysis}

The wind data was collected by the Fort Huachuca meteorological team using a standardized acquisition system they developed in previous years. This system produces the data in a daily report format in ASCII files. The data includes temperature, relative humidity, pressure, average wind direction, average wind speed, and peak wind speed at 2 to 3 heights, every 15 minutes. Unfortunately, the report format stripped all decimal information in its presentation of the data, displaying mean wind speeds with only one significant digit. However, statistics will help mitigate this problem, as most of our analyses will look at averages of collections of these values.

The measurements heights were $7.6 \mathrm{~m}(25 \mathrm{ft})$ and $13.7 \mathrm{~m}(45 \mathrm{ft})$ at all sites, plus $30.5 \mathrm{~m}(100 \mathrm{ft})$ at DCP 2/18. The period of measurement was July, 1995 through June, 1996. All comparisons of meteorological data in this report will refer to the evaluation height of $13.7 \mathrm{~m}(45 \mathrm{ft})$, unless otherwise noted.

Analysis of this data required several steps for each data set (DCP):

1. Assemble all data into a single file, using a MS Excel spreadsheet macro to import each daily report and strip out header and summary information.

2. Visually scan these files for a variety of data errors, noting omissions, text values and other anomalies, and repairing data segments with incorrect time shifts.

3. Perform a series of statistical analyses on each data set, including summary statistics, frequency distributions, annual and seasonal records, and annual and seasonal average diurnals.

\subsection{WIND RESOURCE}

In November, 1994, NREL entered into a cooperative agreement in which the Fort Huachuca meteorological team would collect one year of high quality wind resource data at several sites and an NREL team would analyze the data and evaluate the sites for wind energy production in cooperation with the Fort Huachuca. Energy Manager. We examined this data in detail, and reviewed available historical data summaries in order to describe a long-term behavior.

\subsection{Historical Wind Data}

The wind resource at most sites varies from year to year and, in fact, it can vary widely. For this reason, it is prudent to review long-term data at the nearest site available. Therefore, this section begins with a review of 17 years of wind speed data (1954-1971) at the Fort Huachuca station number 03124 , compiled by Pacific Northwest Laboratories and managed by the National Climatic Data Center [5]. Newer data is not yet available. Located at 31.35 deg latitude and $-110.20 \mathrm{deg}$ longitude, this station measured hourly wind speed at $4 \mathrm{~m}$ height 24 times per day. 
Information is not available on quality control of these measurements; they carry risks such as wind obstruction and drifting calibrations. Some bias toward lower wind speed measurements might be expected because of ground drag, obstructions, or binding anemometers, but no attempt is made to account for such bias in this study. Therefore, the averages found here will not be used for the wind energy modeling later in this report, but the interannual variability found will be used for a sensitivity analysis.

Historical annual average wind speeds follow in Figure 8. The average 17 year wind speed at Fort Huachuca at the $4 \mathrm{~m}$ data collection height is $3.0 \mathrm{~m} / \mathrm{s}(6.7 \mathrm{mph})$ based on annual averages of hourly data, and the average of the annual standard deviations is $2.3 \mathrm{~m} / \mathrm{s}(5.1 \mathrm{mph})$. The standard deviation of the annual averages is $0.27 \mathrm{~m} / \mathrm{s}(0.61 \mathrm{mph})$, giving a coefficient of variation of $0.27 / 3.0=0.090$, or $9 \%$. The interannual variability of $9 \%$ is relatively low indicating reasonably stable year-to-year conditions.

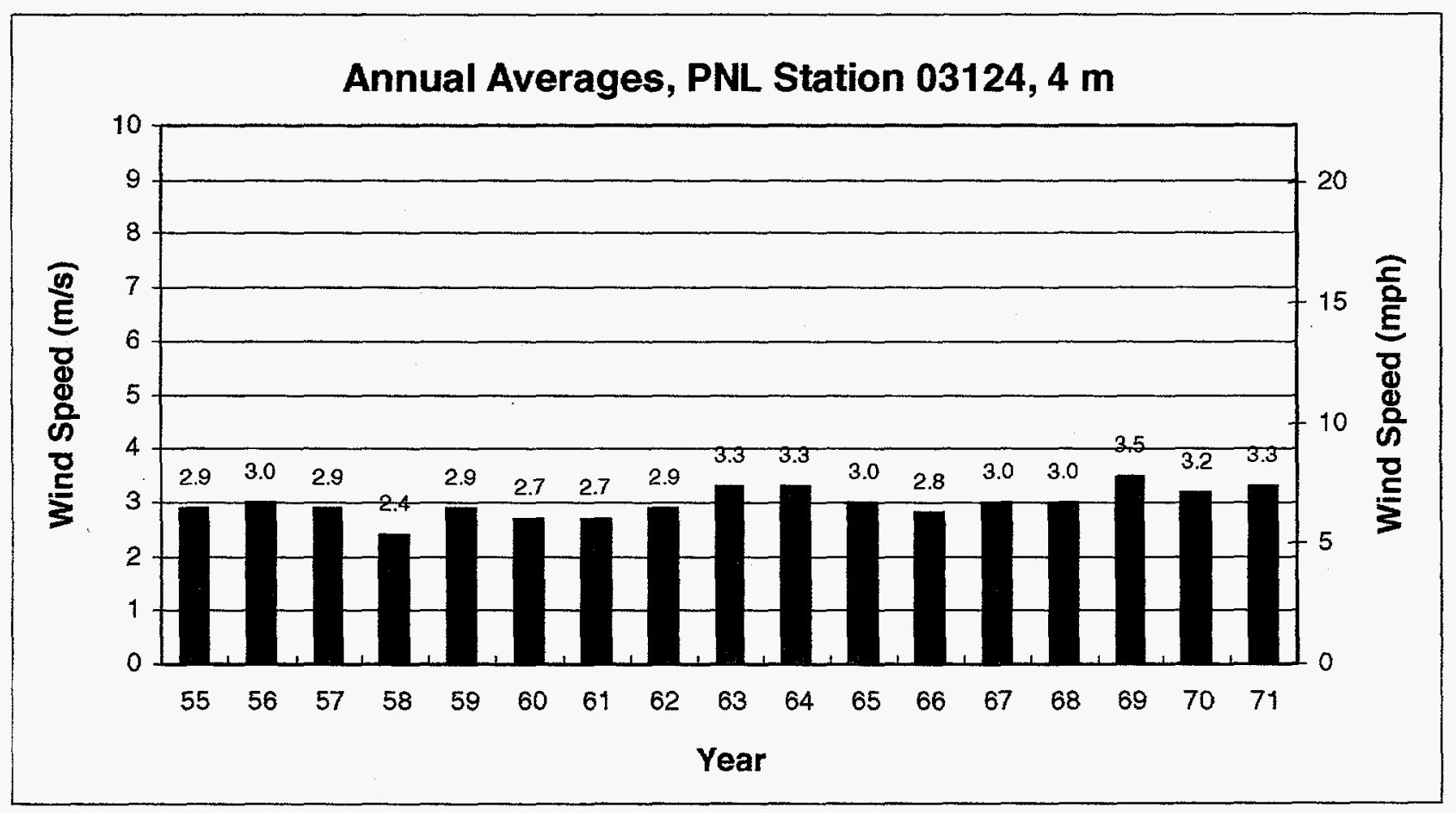

Figure 8: Fort Huachuca Historical Wind Speeds

\subsection{Current Wind Data}

Statistical analysis of the full year of Fort Huachuca 15-minute data yielded the results shown in Table 1, and a full wind-speed distribution is presented in Figure 9. Collected at 7.6, 13.7, and $30.5 \mathrm{~m}$ heights, the data revealed rather modest wind speeds, with the best average of $5.0 \mathrm{~m} / \mathrm{s}$ occurring at $13.7 \mathrm{~m}$ at DCP16. However, these are somewhat low measurement levels. Wind turbine tower heights typically range from $24 \mathrm{~m}(79 \mathrm{ft})$ to $50 \mathrm{~m}(164 \mathrm{ft})$. Although canyon "drainage" flows were expected (winds amplified by terrain funneling low in the canyons), it was 
not clearly demonstrated, as accurate wind direction data was not available. However, significant positive wind shears were found. The wind shear exponents varied from 0.22 to 0.49 , all higher than the typical $1 / 7$ power law (0.143).

Table 1: Summary of Current Fort Huachuca Meteorological Data

West Gate, DCP 2, 13.7 m:

\begin{tabular}{llrrrrr} 
& & & & \multicolumn{2}{c}{ Coefficient of } \\
Channel & Units & Average & $\begin{array}{r}\text { Standard } \\
\text { Deviation }\end{array}$ & Minimum & Maximum & Variation \\
Wind Speed & $\mathrm{m} / \mathrm{s}$ & 3.9 & 2.3 & 0.0 & 16.1 & 0.59 \\
Wind Speed & $\mathrm{mph}$ & 8.7 & 5.2 & 0.0 & 36.0 & 0.60 \\
Ambient Temperature & ${ }^{\circ} \mathrm{C}$ & 18.9 & 8.0 & -2.2 & 51.7 & 0.42 \\
Ambient Pressure & $\mathrm{mbar}$ & 843 & 2.8 & 817 & 866 & 0.00 \\
Air Density & $\mathrm{kg} / \mathrm{m}^{3}$ & 1.01 & 0.00 & 0.93 & 1.05 & 0.00 \\
Power Density & $\mathrm{W} / \mathrm{m}^{2}$ & 49 & 11 & 1 & 3201 & 0.22 \\
Wind Shear Exponent & $\left(25^{\prime}\right.$ to 45') & 0.49 & & & & \\
Wind Shear Exponent & $\left(45^{\prime}\right.$ to $\left.100^{\prime}\right)$ & 0.22 & & & & \\
Wind Shear Exponent & $(25$ ' to 100') 0.33 & & & & & \\
Mean Diurnal Variation & $\mathrm{m} / \mathrm{s}$ & $+/-1.1$ & & & &
\end{tabular}

Bore Site, DCP 13, $13.7 \mathrm{~m}$ :

\begin{tabular}{llrrrrr} 
& & & Standard & \multicolumn{2}{c}{ Coefficient of } \\
Channel & Units & Average & Deviation & Minimum & Maximum & Variation \\
\hline Wind Speed & $\mathrm{m} / \mathrm{s}$ & 4.1 & 2.4 & 0.0 & 19.7 & 0.59 \\
Wind Speed & $\mathrm{mph}$ & 9.2 & 5.4 & 0.0 & 44.0 & 0.59 \\
Ambient Temperature & ${ }^{\circ} \mathrm{C}$ & 17.8 & 8.0 & -3.9 & 37.2 & 0.45 \\
Ambient Pressure & $\mathrm{mbar}$ & 820 & 3.0 & 808 & 827 & 0.00 \\
Air Density & $\mathrm{kg} / \mathrm{m}^{3}$ & 0.99 & 0.00 & 0.93 & 1.05 & 0.00 \\
Power Density & $\mathrm{W} / \mathrm{m}^{2}$ & 34 & 7 & 0 & 3751 & 0.21 \\
Wind Shear Exponent & $\left(25^{\prime}\right.$ to $\left.45^{\prime}\right)$ & 0.27 & & & & \\
Mean Diurnal Variation & $\mathrm{m} / \mathrm{s}$ & $+/-0.4$ & & & &
\end{tabular}

TV Hill, DCP 16, $13.7 \mathrm{~m}$ :

\begin{tabular}{llrrrrr} 
& & & Standard & & \multicolumn{2}{c}{ Coefficient of } \\
Channel & Units & Average & Deviation & Minimum & Maximum & Variation \\
Wind Speed & $\mathrm{m} / \mathrm{s}$ & 5.0 & 3.4 & 0.4 & 23.2 & 0.68 \\
Wind Speed & $\mathrm{mph}$ & 11.2 & 7.5 & 1.0 & 52.0 & 0.67 \\
Ambient Temperature & ${ }^{\circ} \mathrm{C}$ & 14.9 & 7.6 & -6.1 & 36.7 & 0.51 \\
Ambient Pressure & $\mathrm{mbar}$ & 791 & 3.4 & 771 & 799 & 0.00 \\
Air Density & $\mathrm{kg}^{3} \mathrm{~m}^{3}$ & 0.96 & 0.00 & 0.90 & 1.01 & 0.00 \\
Power Density & $\mathrm{W} / \mathrm{m}^{2}$ & 61 & 18 & 0 & 6037 & 0.30 \\
Wind Shear Exponent & $\left(25^{\prime}\right.$ to $\left.45^{\prime}\right)$ & 0.35 & & & & \\
Mean Diurnal Variation & $\mathrm{m} / \mathrm{s}$ & +1.1 & & & &
\end{tabular}




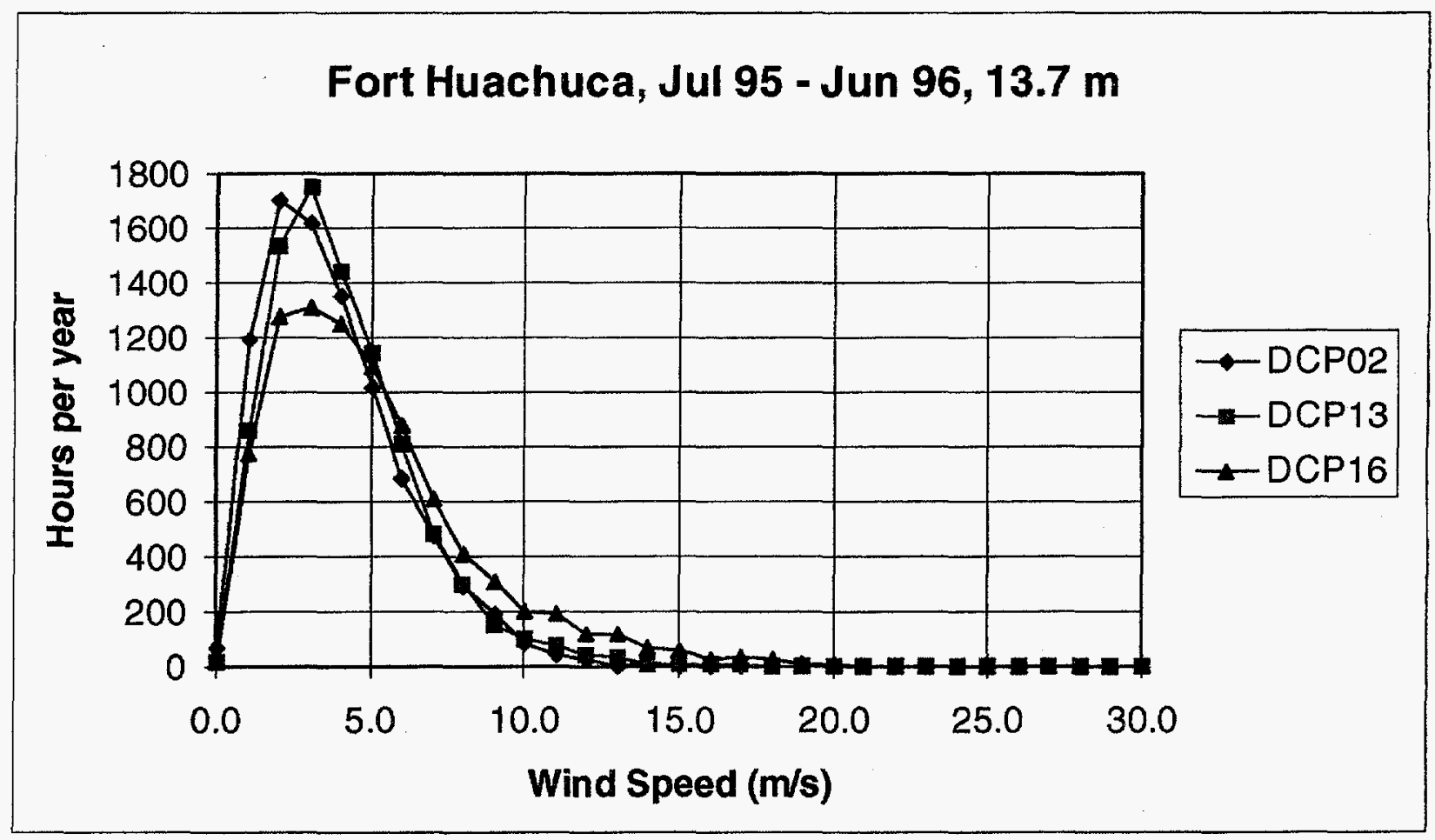

Figure 9: Fort Huachuca Wind Speed Frequency Distribution

Annual records using monthly average wind speeds are plotted in Figure 10. The whole year falls between 3.5 and $6.0 \mathrm{~m} / \mathrm{s}(7.8$ and $13.4 \mathrm{mph})$ at all three sites measured, with lower winds in the fall and higher winds in spring. Fifteen-minute average highs reach $16.0 \mathrm{~m} / \mathrm{s}(35.8 \mathrm{mph})$ in January at DCP16, indicating winter storms. The source data was derived from Fort Huachuca testing as described in section 2.4. The most energetic site of the three examined is DCP16.

The annual average diurnals given in Figure 11 show stable patterns, with hourly mean wind speeds again falling between 3.5 and $6.0 \mathrm{~m} / \mathrm{s}$ (7.8 and $13.4 \mathrm{mph}$ ). However, these are averages; any specific day could be quite different. When reading x-axis (time of day), the column labeled " 0000 " refers to the first hour of the day, 0000 to 0100 . Site DCP02 tends to lull in the morning with higher winds following in the afternoon, while site DCP16 follows with a midday lull and nighttime surge. Site DCP13 tends to hold steady throughout the day.

Additional meteorological data and power density records are given for DCP02 in Figure 12. Ambient temperature and pressure data are used to derive air density, which in turn is used with wind speed to derive wind power density. 


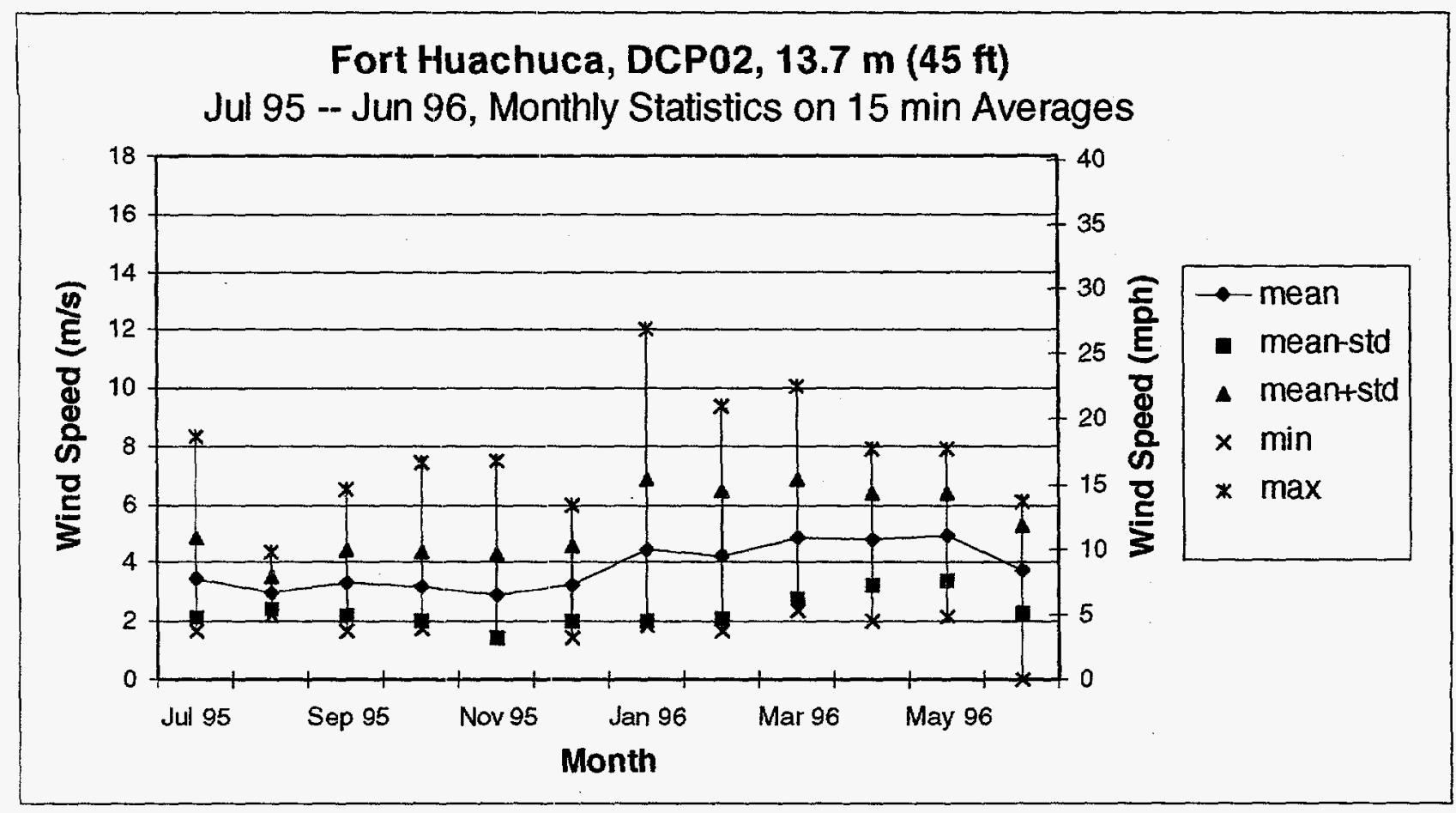

Figure 10a: Fort Huachuca Annual Wind Speed Record, West Gate, DCP02

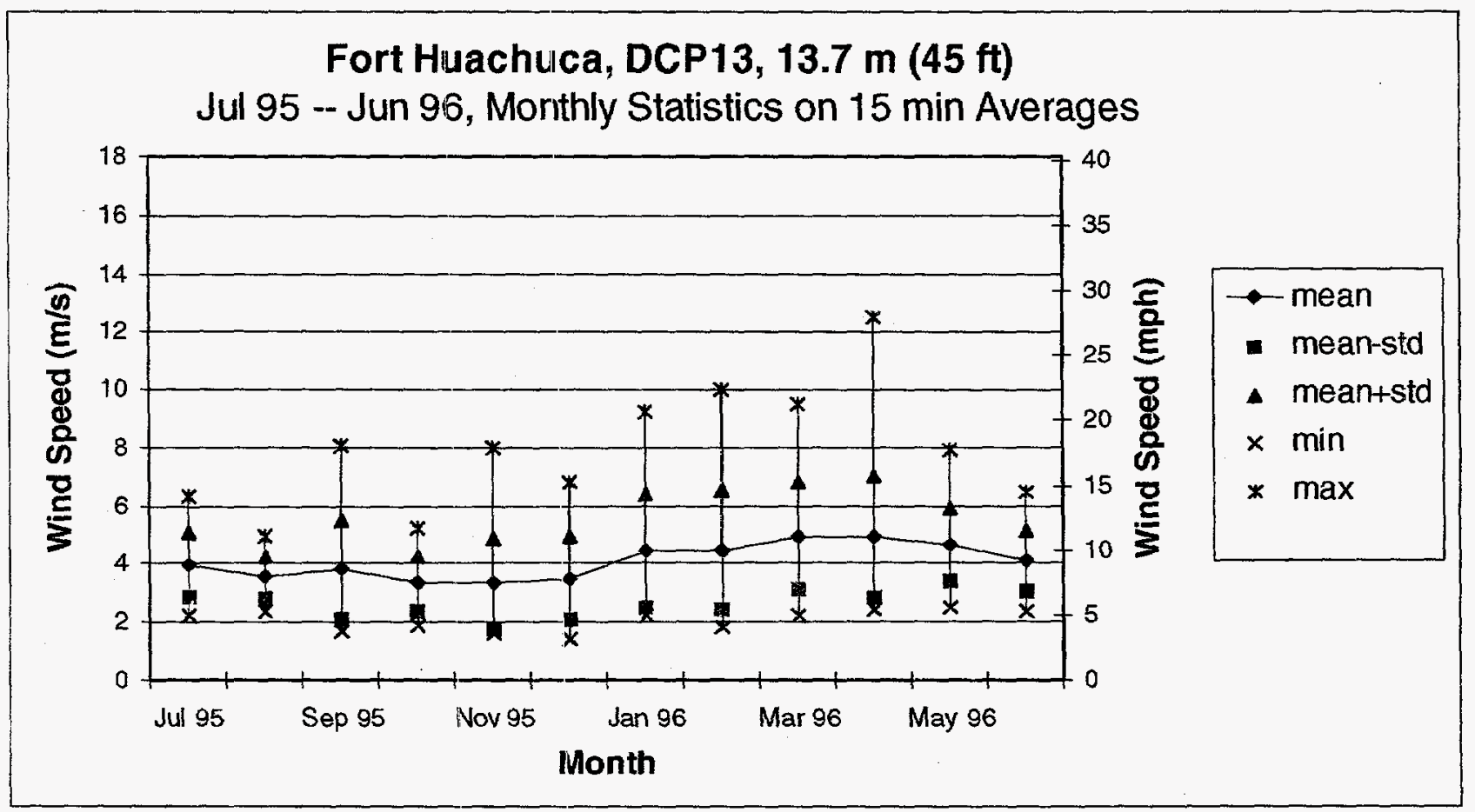

Figure 10b: Fort Huachuca Annual Wind Speed Record, Bore Site, DCP13 


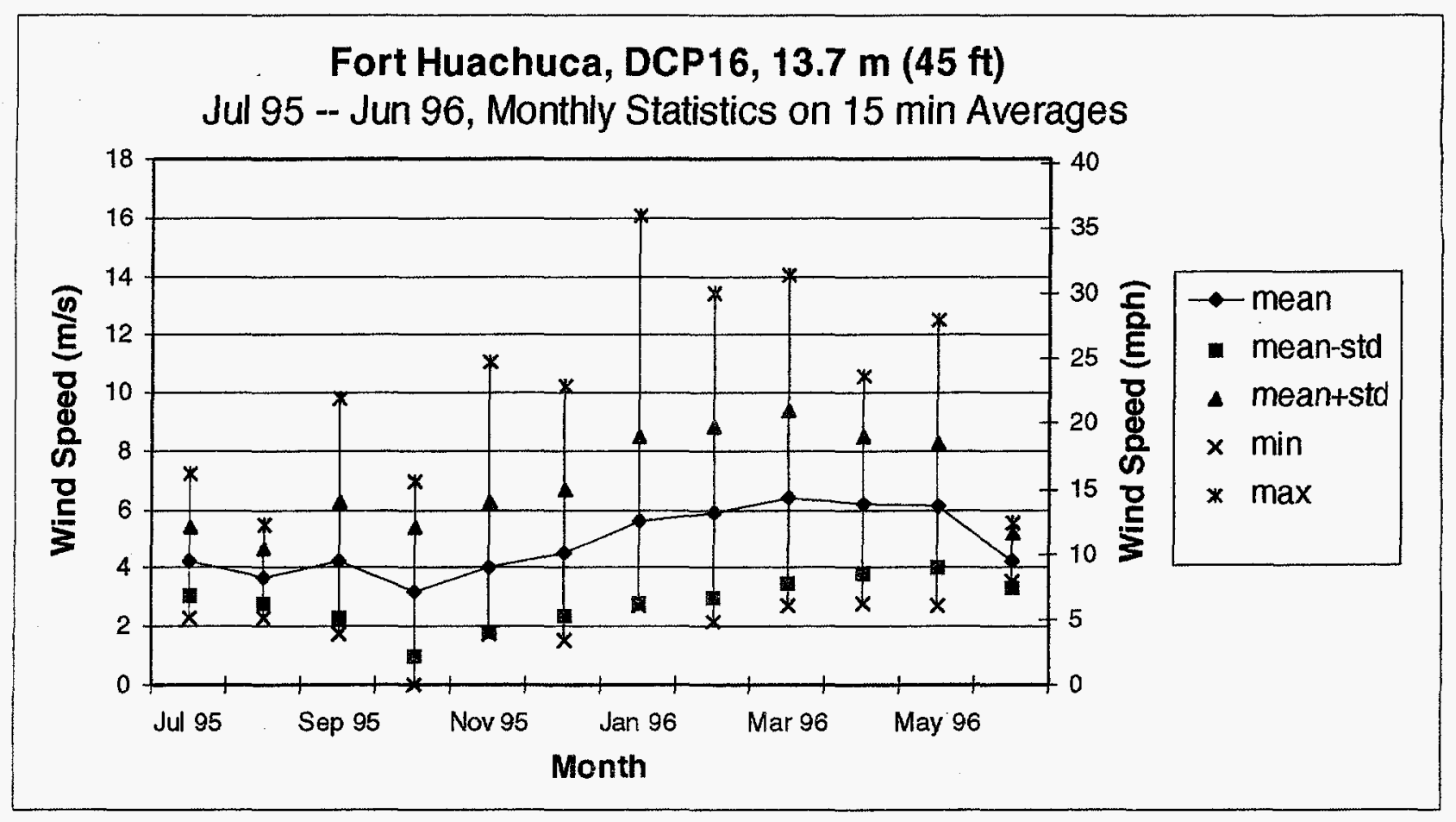

Figure 10c: Fort Huachuca Annual Wind Speed Record, TV Hill, DCP16

Fort Huachuca, DCP02, $13.7 \mathrm{~m}$ (45 ft)

1 Jul 1995 - 30 Jun 1996, Hourly Statistics on 15 min Averages

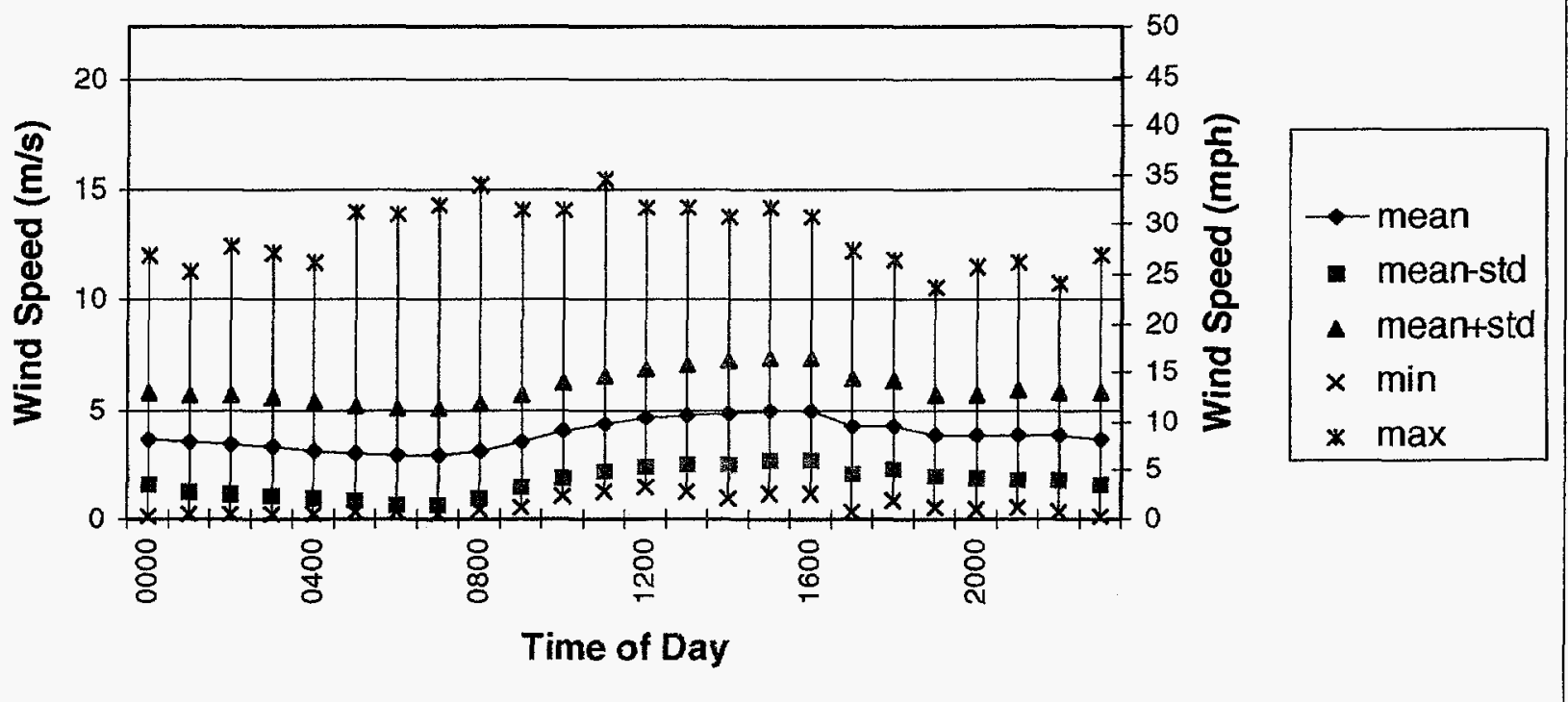

Figure 11a: Fort Huachuca Annual Average Diurnal Wind Speed, West Gate, DCP02 
Fort Huachuca, DCP13, $13.7 \mathrm{~m} \mathrm{(45} \mathrm{ft)}$

1 Jul 1995 -- 30 Jun 1996, Hourly Statistics on 15 min Averages

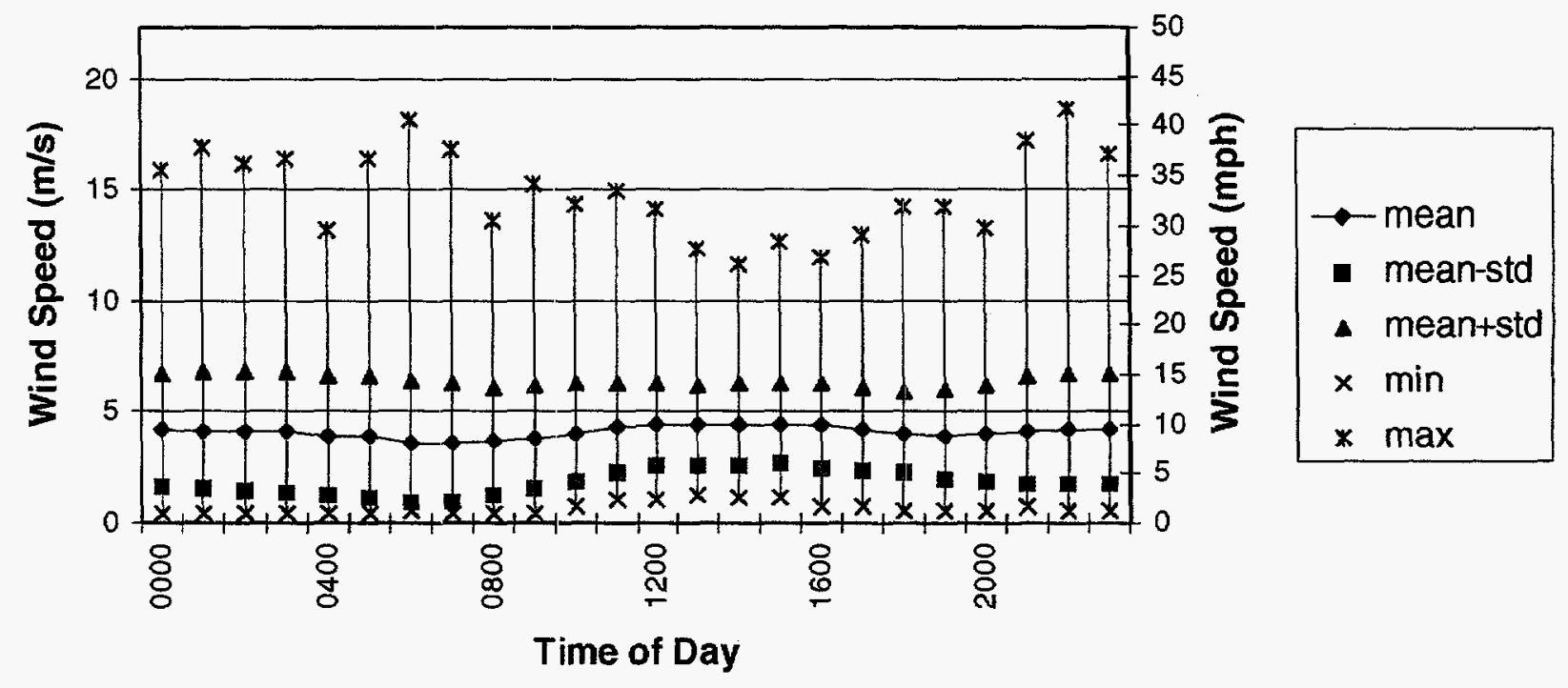

Figure 11b: Fort Huachuca Annual Average Diurnal Wind Speed, Bore Site, DCP13

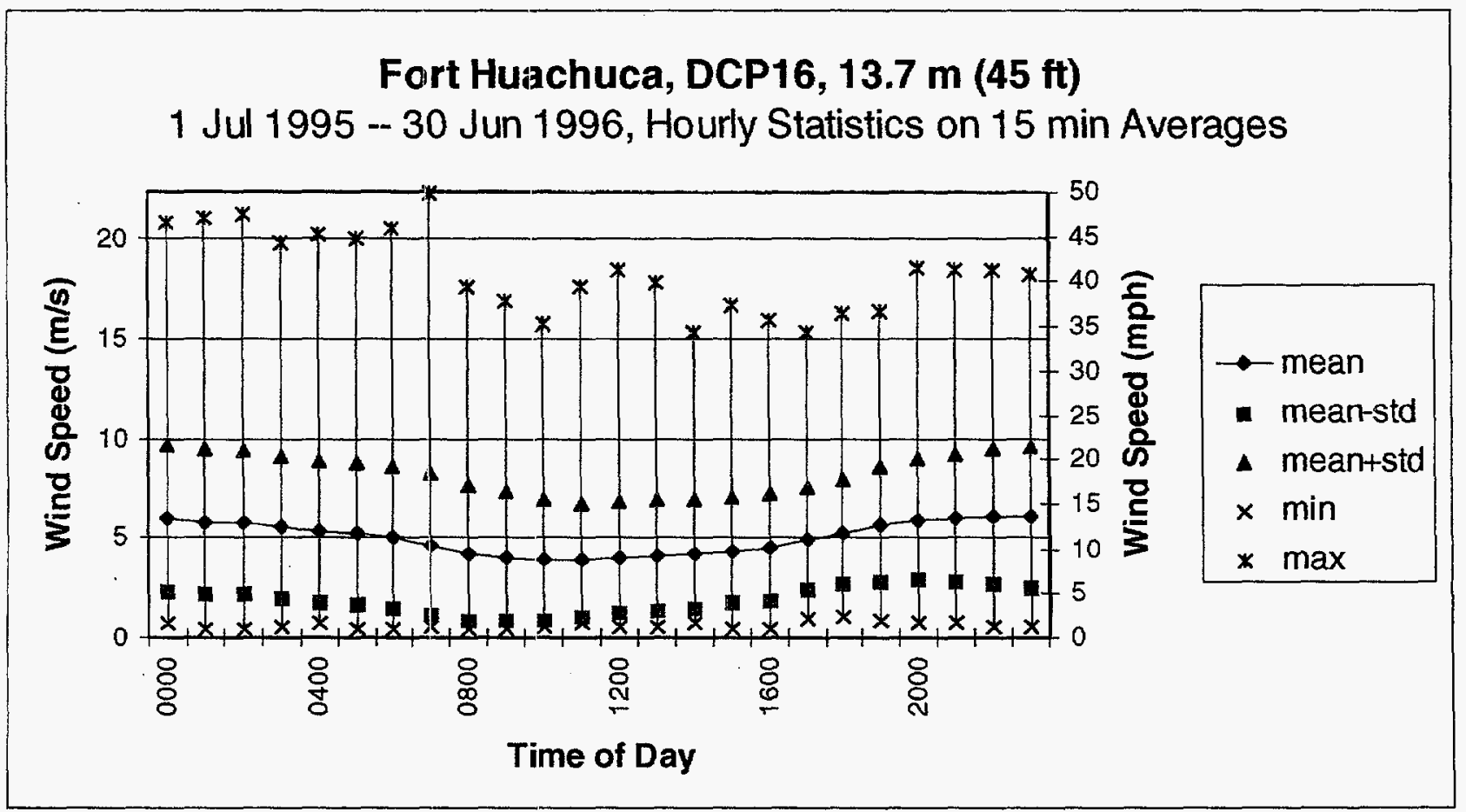

Figure 11c: Fort Huachuca Annual Average Diurnal Wind Speed, TV Hill, DCP16 


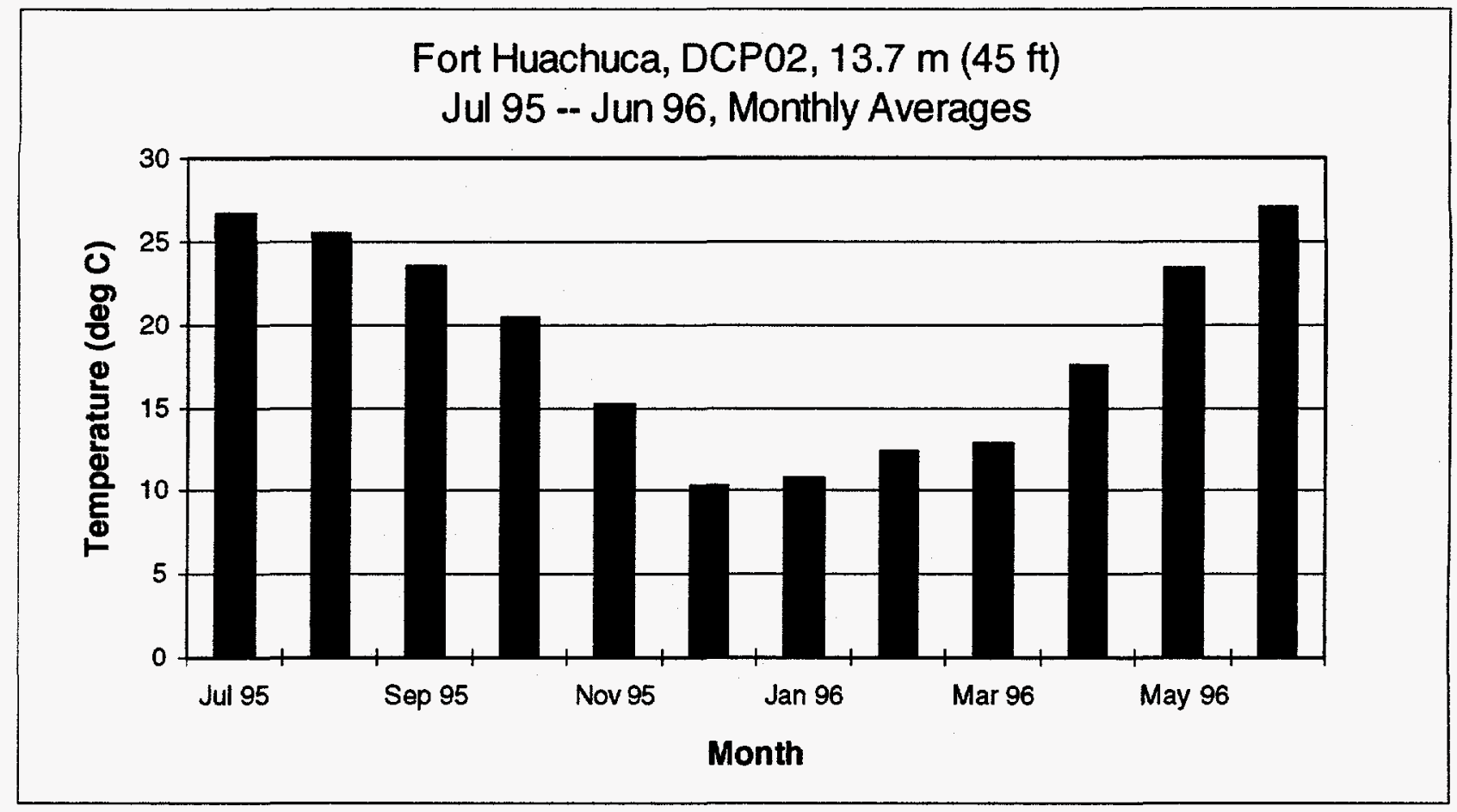

Figure 12a: Other Fort Huachuca West Gate DCP2 Annual Average Data: Temperature

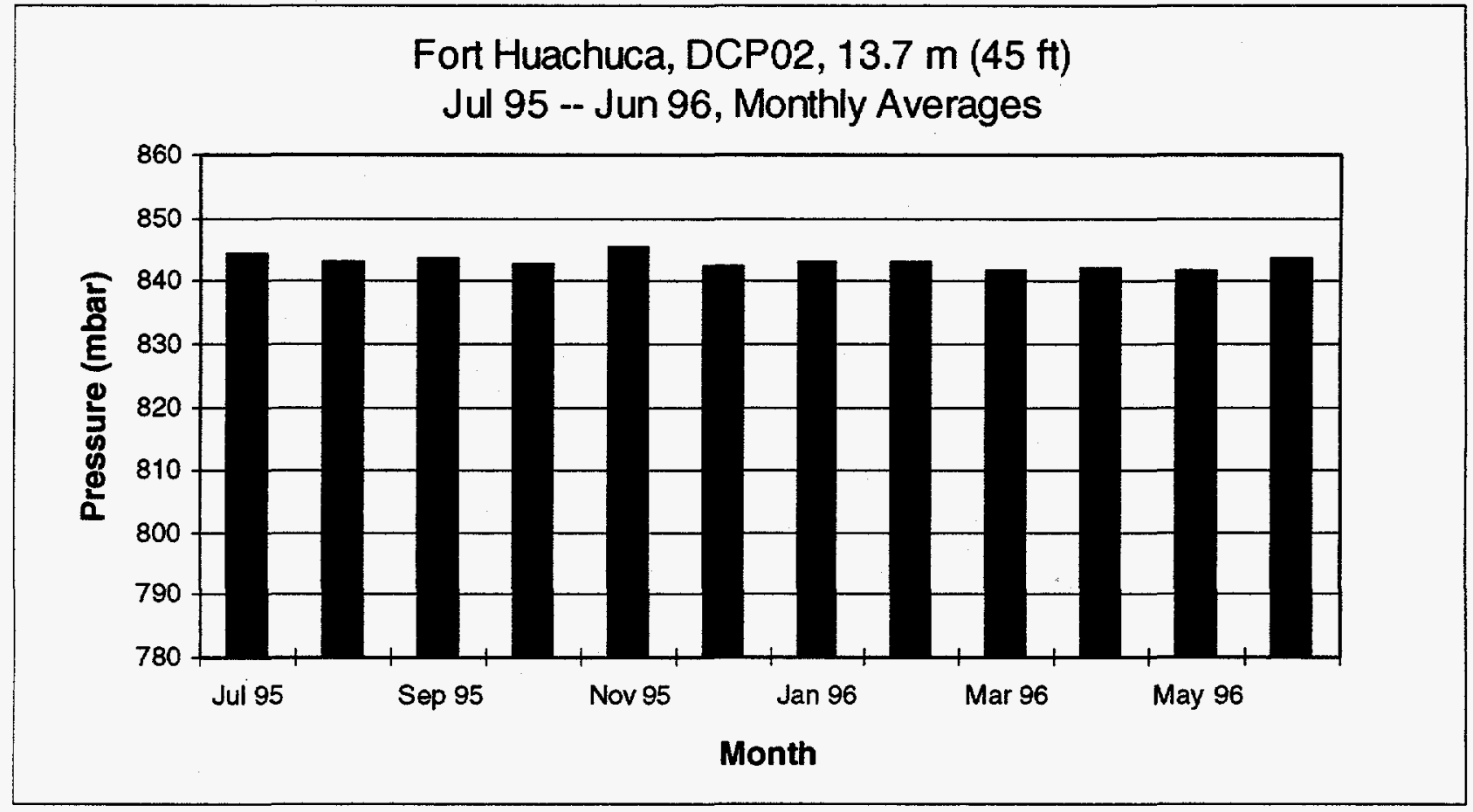

Figure 12b: Other Fort Huachuca West Gate DCP2 Annual Average Data: Pressure 


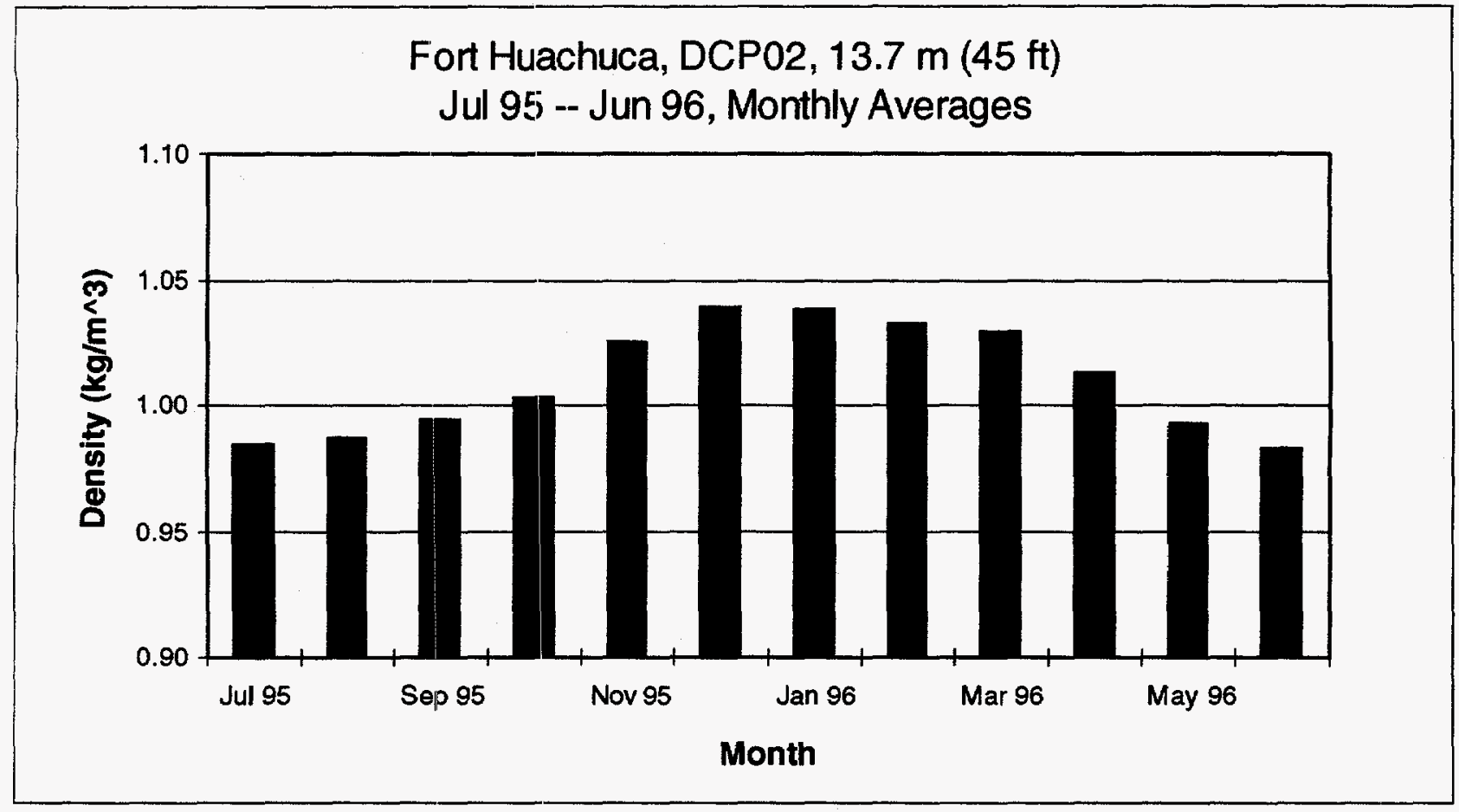

Figure 12c: Other Fort Huachuca West Gate DCP2 Annual Average Data: Air Density

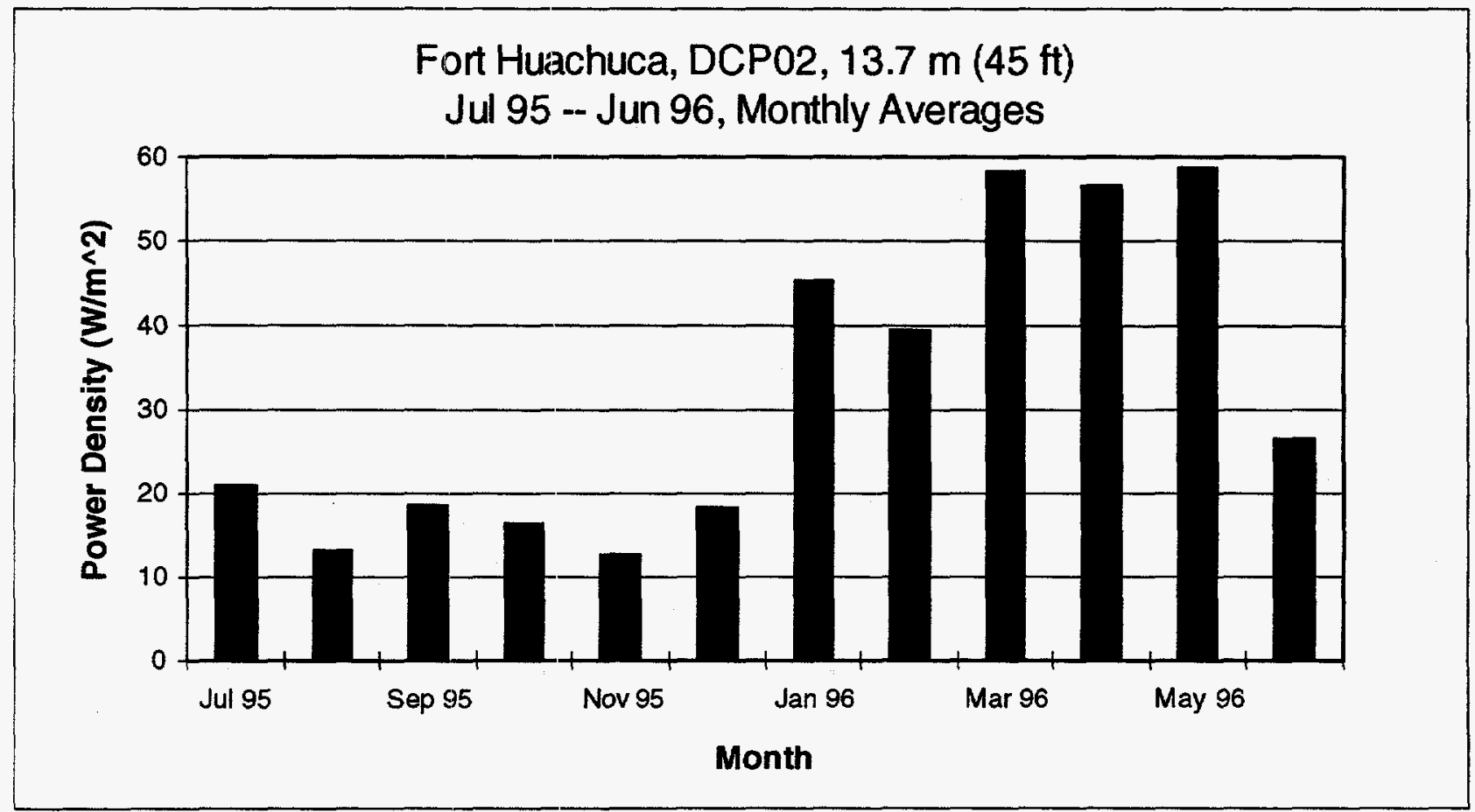

Figure 12d: Other Fort Huachuca West Gate DCP2 Annual Average Data: Wind Power Density 


\subsection{WIND ENERGY COST ANALYSIS}

A wind energy system may be economically and environmentally advantageous for Fort Huachuca and surrounding areas. A preliminary study of such a system was conducted using the author's "WindEcon" spreadsheet program based on the Hunter and Elliott [6] formulation to evaluate the potential energy cost savings from wind generation. Several wind energy cases were compared to help determine the most cost-effective wind farm size.

\subsection{Methodology}

After estimating 1996 operating costs for the wind energy system, the resulting levelized costs of energy (COE), annual energy cost savings and payback periods were estimated. COE is derived according to the National Renewable Energy Laboratory Request for Proposal formulation:

$$
\mathrm{COE}=[(\mathrm{FCR} * \mathrm{ICC})+\mathrm{LRC} / \mathrm{AEP}]+\mathrm{O} \& \mathrm{M},
$$

Where:

$$
\begin{aligned}
& \mathrm{COE}= \text { Levilized Cost of Energy }(\$ / \mathrm{kWh}) \\
& \mathrm{FCR}= \text { Fixed Charge Rate }(1 / \mathrm{yr})=0.109, \text { consists of } 8.0 \% \text { Capital Recovery Factor } \\
& \text { (CRF) plus } 2.9 \% \text { insurance costs } \\
& \mathrm{ICC}=\text { Initial Capital Cost }(\$) \\
& \mathrm{LRC}=\text { Levelized Replacement Cost }(\$ / \mathrm{yr}) \\
& \mathrm{AEP} \mathrm{P}_{\text {net }}=\text { Net Annual Energy Production }(\mathrm{kWh} / \mathrm{yr}) \\
& \mathrm{O \& M}=\text { Annual Operation and Maintenance Cost }(\$ / \mathrm{kWh})
\end{aligned}
$$

A simple payback period is calculated by dividing the total initial capital cost by the annual savings from system operation.

Economic assumptions included 3\% general inflation, 3\% energy inflation, $10.9 \%$ fixed charge rate (FCR), 6.9\% discount rate, 10\% interest rate, 30-year system life, and 100\% down payment on new investment [NREL RFP]. It was further assumed that no additional labor would be required to operate the wind energy system beyond that already assigned to operate the extensive base facilities.

\subsection{Existing Energy Costs}

Fort Huachuca consumed 107.6 million $\mathrm{kWh}$ of electricity in 1996, at a cost of $\$ 7.4$ million. Consumption grew at an average of 3.3\% per year over the last decade but just $1 \%$ over the previous year. The energy bill grew a little faster, with $6.6 \%$ annual average for the decade and $1.4 \%$ in the past year. Peak demand grew from $16,400 \mathrm{~kW}$ in 1987 to $21,300 \mathrm{~kW}$ in 1994 , and then dropped to $19,360 \mathrm{~kW}$ in 1997. Both the slowed consumption growth and the reduced peak demands are a tribute to the success of the ongoing energy conservation program at Fort Huachuca. 
Currently, Tucson Electric Power (TEP) Company bills Fort Huachuca at the rate of 0.047457 per $\mathrm{kWh}$ plus a demand charge of $\$ 10.28$ per $\mathrm{kW}$ based on the peak demand for the month. Using May 1996 as a sample month, the peak demand of $18,392 \mathrm{~kW}$ and energy consumption of $9,254,400$ $\mathrm{kWh}$ give base costs of $\$ 628,257$. Adding a power factor adjustment and taxes raise the total bill up $5.3 \%$ to $\$ 661,586$, or about $\$ 0.0715$ per $\mathrm{kWh}$. Details of the demand profile are not available.

\subsection{Wind Generation System}

The wind generation system modeled consists of eight commercial wind turbines rated at $225 \mathrm{~kW}$ each. The sea level power curve for this turbine is shown in Figure 13. An elevation correction

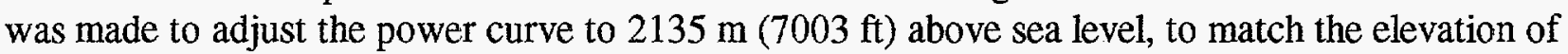
a proposed wind site at TV Hill (DCP 16). This correction is applied by reducing the power at low winds by $21 \%$ (for $2134 \mathrm{~m}$, or $7000 \mathrm{ft}$ elevation), and then fairing in the power to level off at $210 \mathrm{~kW}$ at higher winds. The wind turbines can be curtailed (shut down) as necessary when excess wind energy is available.

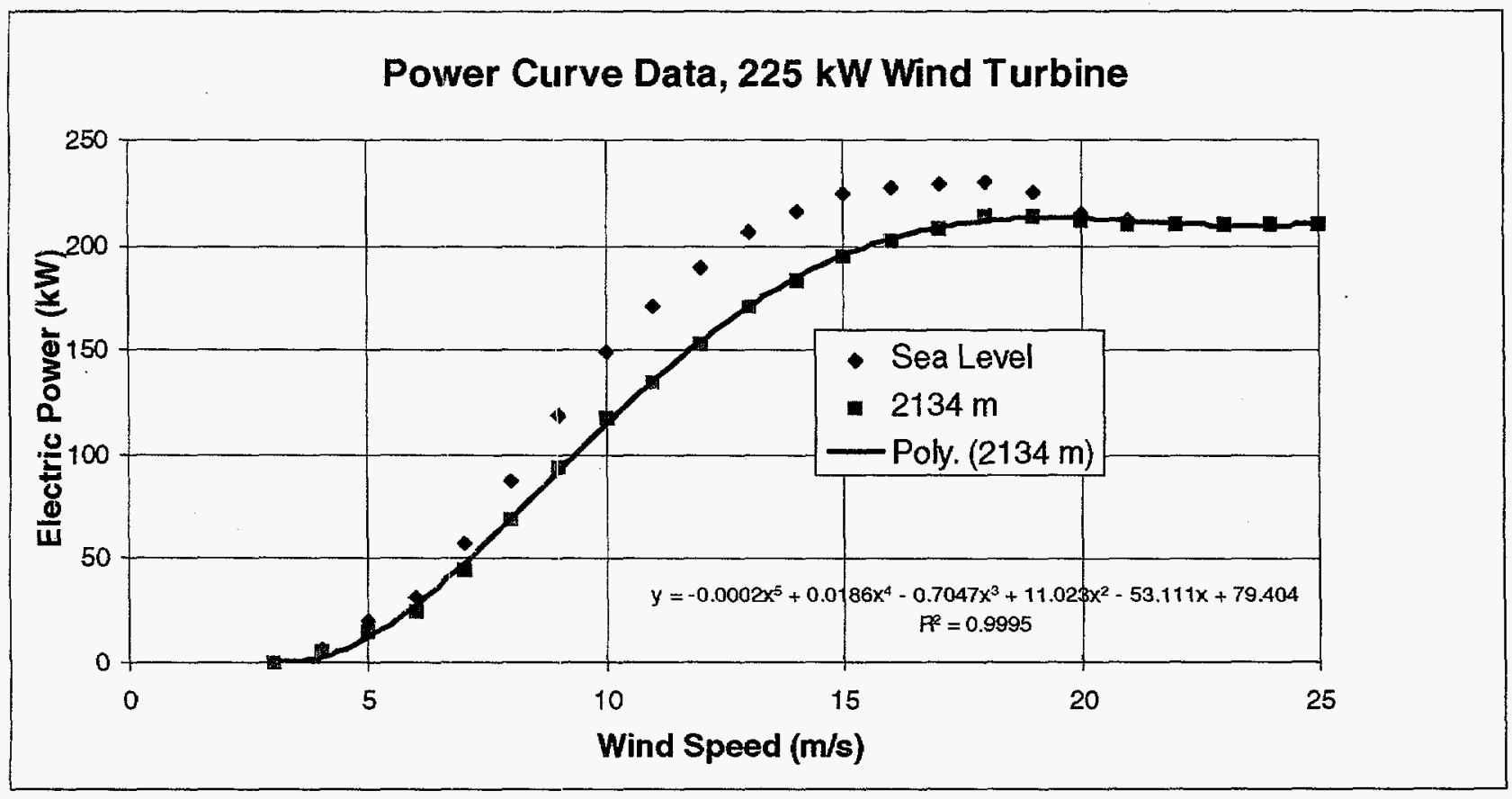

Figure 13: Power Curve, $225 \mathrm{~kW}$ Wind Turbine

The proposed wind energy system is relatively simple. Eight commercially available wind turbines (each with a capacity of $225 \mathrm{~kW}$ ) would be interconnected with the existing TEP grid, for a total rating of $1.8 \mathrm{MW}$. With a demand peak of $19,600 \mathrm{~kW}$ and eight wind turbines, this would constitute wind penetration of peak capacity of $1800 \mathrm{~kW} / 19,600 \mathrm{~kW}=9.2 \%$. Based on a capacity factor of $25 \%$ and annual energy consumption of 108 million $\mathrm{kWh}$, wind penetration 
would be $0.25 * 1800 \mathrm{~kW} * 730 \mathrm{hrs} / 108 \mathrm{kWh}=3.0 \%$. Such low penetration allows the assumption that all available wind energy is utilized.

\subsection{Wind Profile and Energy Production}

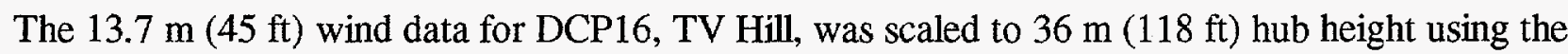
power law exponent of 0.35 . This raises the average wind speed from $5.00 \mathrm{~m} / \mathrm{s}(11.1 \mathrm{mph})$ to $7.03 \mathrm{~m} / \mathrm{s}(15.7 \mathrm{mph})$. The new distribution appears in Figure 14.

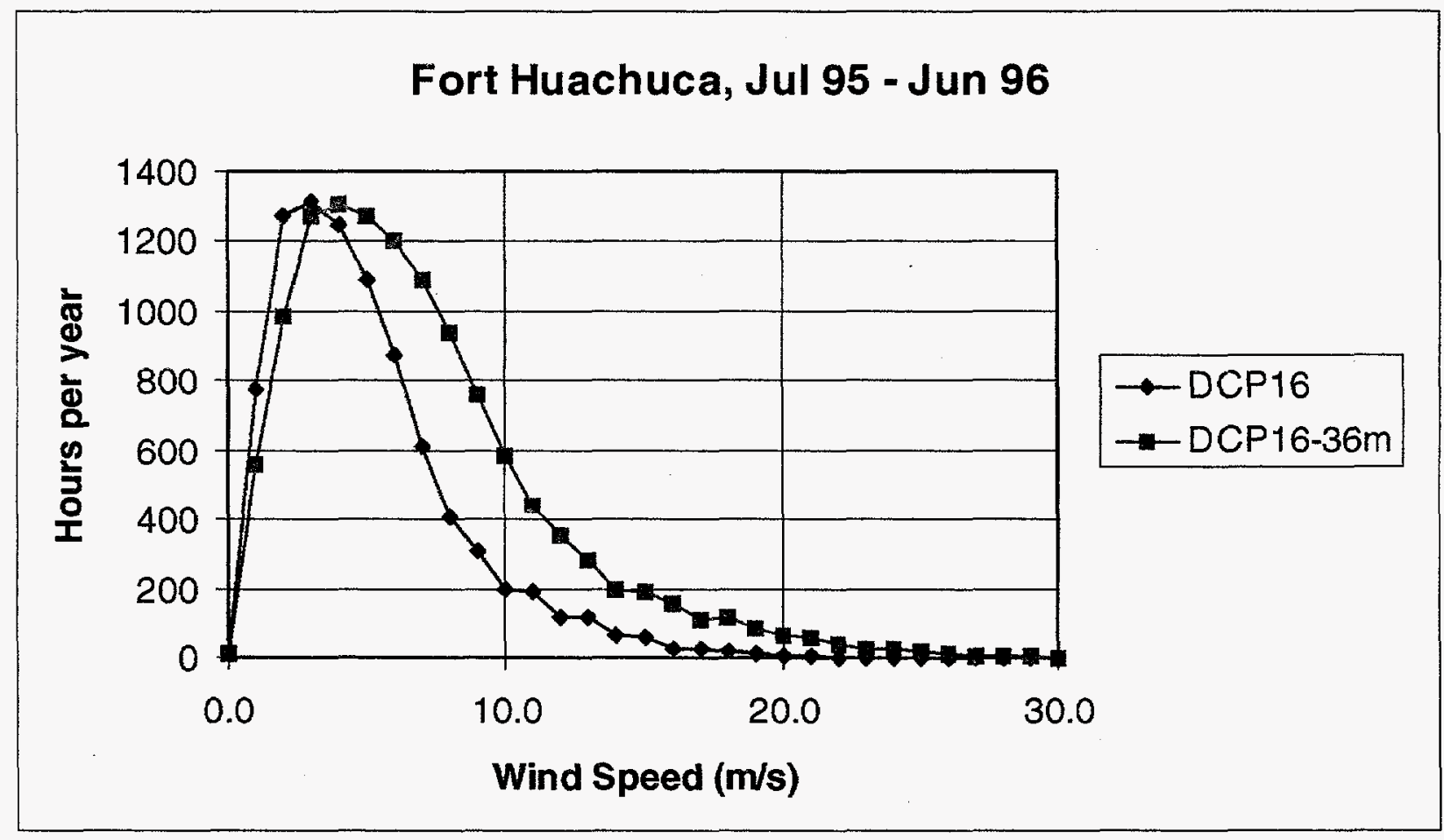

Figure 14: TV Hill, DCP16 Wind Distribution Scaled to $36 \mathrm{~m}$

The net annual energy production (AEP) can be computed by multiplying the power production level by the number of hours for each wind speed level and summing the results. If $\mathrm{P}_{\mathrm{i}}$ is power and $N_{i}$ is number of hours at each wind speed, then:

$$
\operatorname{AEP}=\operatorname{sum}\left(P_{i} * N_{i}\right), \quad i=0.0,0.5,1.0, \ldots 100.0 \mathrm{~m} / \mathrm{s} .
$$

Actual AEP is often lower because of various system losses. The assessment of the wind site showed that there are not any significant obstructions to the prevailing wind flow. Also, there is plenty of room for eight wind turbines, so array losses should be mitigated with proper siting. However, other sources of loss cannot be avoided as easily. They include $1 \%-5 \%$ availability loss for operation and maintenance, possibly $5 \%$ for blade soiling losses, $2 \%$ for turbulence losses, and 
$3 \%$ for control, grid, and collection system losses. Using $97 \%$ availability, the combination of these sources is significant, having a net loss of $11.5 \%$.

Convolving the power curve shown in Figure 13 with the $36 \mathrm{~m}$ wind distribution shown in Figure 14 gives an AEP of $498,727 \mathrm{kWh}$ per year per turbine. After $11.5 \%$ losses, net AEP is $441,373 \mathrm{kWh}$ per turbine.

\subsection{Wind Generation System Costs}

Wind energy system initial capital costs (ICC) include all costs associated with the wind turbines and interconnect and control equipment. The interconnect and control equipment are included with the wind turbine balance of station (BOS) costs, along with foundations, installation, spare parts inventory, site surveying and preparation, O\&M facilities and equipment, permits and licenses, project management and engineering, and construction insurance and contingency. BOS costs are detailed in Table 2. (Note: It may be possible to further reduce installation and operation costs by adding DoD excess heavy equipment [e.g. a crane] to Fort Huachuca inventory.)

\section{Table 2: Balance of Station Costs for Eight $225 \mathrm{~kW}$ Wind Turbines}

\begin{tabular}{lr} 
Item & 1995 Cost \\
\hline Electrical Infrastructure & $\$ 100,000$ \\
Control \& Monitoring Equipment & 30,000 \\
Foundations & 100,000 \\
Installation & 250,000 \\
Spare Parts & 19,000 \\
Site Survey \& Preparation & 50,000 \\
Permits \& Licenses & 10,000 \\
Environmental Assessment & 10,000 \\
Project Management \& Engineering & 200,000 \\
Construction Insurance \& Contingency & 67,000 \\
Training & 11,000 \\
Shipping & $\underline{40,000}$ \\
\multicolumn{1}{c}{ Total } & $\$ \underline{88,000}$
\end{tabular}

Meteorological Instrumentation System (optional) $\$ 34,000$

Each $225 \mathrm{~kW}$ wind turbine, including a $24.4 \mathrm{~m}(80) \mathrm{ft}$ tower, costs approximately $\$ 250,000$. An additional $\$ 111,100$ has been allotted to cover BOS costs. BOS costs are highly site dependent and can vary by an order of magnitude. The total ICC required then for each wind turbine is $\$ 361,100$.

Levelized parts replacement costs (L,RC) are fixed at an annual $\$ 1000$ per wind turbine, regardless of turbine usage. 
Actual wind turbine O\&M costs are expected to be $\$ 40,000$ for eight turbines, giving a per-energy rate of $\$ 0.0115 / \mathrm{kWh}$. As implied by its units, this O\&M cost is variable, or fully dependent on wind turbine usage. These estimates are based on working systems using the sample $225 \mathrm{~kW}$ wind turbine and are fairly conservative.

\subsection{Wind Energy Cost Comparison}

The NREL RFP calculation gives an uncompetitive COE result for a small wind system at this site:

$$
\begin{aligned}
& \mathrm{COE}=[(\mathrm{FCR} * \mathrm{ICC})+\mathrm{LRC}] / \mathrm{AEP}+\mathrm{O} \& \mathrm{M} \\
& \mathrm{COE}=[(0.109 * \$ 361,100)+\$ 1000] / 441,373 \mathrm{kWh}+\$ 0.0115 / \mathrm{kWh} \\
& \mathrm{COE}=\$ 0.103 / \mathrm{kWh} .
\end{aligned}
$$

However, it is likely the US Army would pay the initial capital costs in cash rather than through financing, in which case the fixed charge rate is not accurate. So a net present value formulation is used instead (Appendix A). This approach actually gives a higher COE for the grid energy payments. Because of the 3\% inflation and 30 year life assumptions, levelized grid energy COE is $\$ 0.101 / \mathrm{kWh}$, while the wind energy COE is $\$ 0.085 / \mathrm{kWh}$ and the combined system COE is $\$ 0.100 / \mathrm{kWh}$. This reduction in system COE is minimal. The $\$ 2.89 \mathrm{M}$ capital investment in the eight wind turbine system was offset by energy bill savings of $\$ 202,000$ annually, giving a 14.3 year simple payback period with $5.7 \%$ internal rate of return (IRR). These results also are presented in Table 3.

Fort Huachuca probably could handle a much larger wind farm and fully utilize wind energy with penetrations up to $30 \%$. However the economic benefit is marginal at this point, and would require lower wind system costs or higher grid energy rates to improve. Currently available used wind generating equipment may be the key to much more beneficial economics. 
Talble 3: 1996 Wind Energy System Economics

\begin{tabular}{llrr} 
& Units & $\begin{array}{r}\text { Baseline } \\
\text { Grid Only } \\
0 \mathrm{~kW}\end{array}$ & $\begin{array}{r}+8 \text { Wind } \\
\text { Turbines } \\
1800 \mathrm{~kW}\end{array}$ \\
\hline Parameter & $\mathrm{m} / \mathrm{s}$ & 6.65 & 6.65 \\
Average WS, 1 yr & $\mathrm{kW}$ & 12,290 & 12,290 \\
Average Load, 1 yr & $\mathrm{kW}$ & 12,290 & 11,880 \\
Avg Net Grid Load & & & \\
& $\mathrm{GWh}$ & 107.6 & 107.6 \\
Energy Demand, 1yr & $\mathrm{GWh}$ & 107.6 & 104.1 \\
Grid Energy, 1yr & $\mathrm{GWh}$ & 0 & 3.5 \\
Wind Energy, 1yr & $\mathrm{MWh}$ & 0 & 0 \\
Unused Wind Energy & & & \\
& $\%$ & 100.0 & 96.7 \\
Grid Energy & $\%$ & 0.0 & 3.3 \\
Wind Energy & & $\mathrm{n} / \mathrm{a}$ & 22.4 \\
Wind System Capacity Factor \% & & \\
& & 0.101 & 0.100 \\
Levelized COE & $\$ / \mathrm{kWh}$ & 0.000 & 0.001 \\
COE Saving & $\$ \mathrm{kWh}$ & 0.0 & 1.0 \\
COE Saving & $\%$ of base & & 0.085 \\
Wind COE & $\$ / \mathrm{kWh}$ & & 14.3 \\
Payback Period & year & $\mathrm{n} / \mathrm{a}$ & 5.7 \\
Internal Rate of Return & $\%$ & $\mathrm{n} / \mathrm{a}$ &
\end{tabular}

Notes: (1) "Net Grid Load" means net power required from the grid, or system load minus useable wind power.

(2) Wind System Capacity Factor = Wind Energy [MWh] / (\#turbines*rating[0.225MW]*8760[h]).

(3) All other values derived from spreadsheet model results, Appendix A. 


\subsection{Wind Speed Sensitivity}

To check the sensitivity of the results to variations in average wind speed from year to year, the two turbine case was run with the wind speeds adjusted upward and downward by $9 \%$, which is the interannual variability found in the historical wind measurements. The results are shown in Table 4. With the wind speed 9\% lower than the NREL measurement year, wind energy COE and payback period rose by $13 \%$ and $17 \%$. With the wind speed $9 \%$ higher, COE and payback period dropped by $11 \%$ and $13 \%$. In both cases, the total system COE is nearly unchanged, because of the low wind energy penetration.

Table 4: Economic Sensitivity to Wind Speed Variations Spreadsheet Model for 8 Turbines

\begin{tabular}{|c|c|c|c|c|c|}
\hline Case & Wind Speed & $\begin{array}{c}\text { Energy bill } \\
\text { Saving } \\
(\$ 1000)\end{array}$ & $\begin{array}{c}\text { Wind } \\
\text { COE } \\
(\$ / \mathrm{kWh})\end{array}$ & $\begin{array}{c}\text { Payback } \\
\text { Period } \\
\text { (years) }\end{array}$ & $\begin{array}{c}\text { Internal } \\
\text { Rate of } \\
\text { Return (\%) }\end{array}$ \\
\hline minus $9 \%$ & $6.4 \mathrm{~m} / \mathrm{s}$ & 173 & 0.096 & 16.7 & 4.3 \\
\hline baseline & $7.0 \mathrm{~m} / \mathrm{s}$ & 202 & 0.085 & 14.3 & 5.7 \\
\hline plus $9 \%$ & $7.7 \mathrm{~m} / \mathrm{s}$ & 231 & 0.076 & 12.5 & 6.9 \\
\hline Case & Wind Speed & $\begin{array}{c}\text { Energy bill } \\
\text { Saving } \\
(\text { delta } \%) \\
\end{array}$ & $\begin{array}{c}\text { Wind } \\
\text { COE } \\
\text { (delta \%) } \\
\end{array}$ & $\begin{array}{c}\text { Payback } \\
\text { Period } \\
(\text { delta \%) }\end{array}$ & $\begin{array}{c}\text { Internal } \\
\text { ROR } \\
(\operatorname{delta} \%) \\
\end{array}$ \\
\hline minus $9 \%$ & $6.4 \mathrm{~m} / \mathrm{s}$ & -14 & 13 & 17 & -25 \\
\hline baseline & $7.0 \mathrm{~m} / \mathrm{s}$ & 0 & 0 & 0 & 0 \\
\hline plus $9 \%$ & $7.7 \mathrm{~m} / \mathrm{s}$ & 14 & -11 & -13 & 21 \\
\hline
\end{tabular}




\subsection{CONCLUSIONS}

Fort Huachuca has a marginal wind resource, with annual average wind speeds of 3.9 to $5.0 \mathrm{~m} / \mathrm{s}$ ( 8.7 to $11.2 \mathrm{mph}$ ) as measured by the Fort Huachuca meteorological team at $13.7 \mathrm{~m} \mathrm{(} 45 \mathrm{ft}$ ) height at three collection sites on the base between 1 July 1995 and 30 June 1996. Somewhat helpful, though, are strong positive vertical wind shears with exponents of 0.22 to 0.49 . The wind speed at DCP16 had a shear factor of 0.35 , which scales the wind speeds up to $7.0 \mathrm{~m} / \mathrm{s}(15.7 \mathrm{mph})$ at a wind turbine hub height of $36 \mathrm{~m}(118 \mathrm{ft})$. Recognizing this, a wind energy system was evaluated to examine the merits of supplementing grid energy from Tucson Electric Power (TEP) with a modest portion of wind energy generation: $1.8 \mathrm{MW}$, or $3 \%$ energy penetration or $9 \%$ peak capacity penetration. Using conservative assumptions (unfavorable to wind energy) throughout the analysis, the wind energy system displayed favorable operation and marginal economics. The levelized cost of energy for the wind and grid energy case using eight $225 \mathrm{~kW}$ wind turbines is $\$ 0.100 / \mathrm{kWh}$, essentially unchanged from the baseline case without wind $(\$ 0.101 / \mathrm{kWh})$. The payback period is 14.3 years, the internal rate of return $5.7 \%$. The system COE is relatively insensitive to annual average wind speed, varying less than $1 \%$ for a $9 \%$ change in wind speed. But the wind portion of the COE is more sensitive to wind speed, varying $13 \%$ for a $9 \%$ change in wind speed. The same $9 \%$ change in wind speed causes payback period to change up to $17 \%$, and the internal rate of return to change $25 \%$.

This work presented a preliminary study of a wind energy system using eight $225 \mathrm{~kW}$ wind turbines. For the application and conditions that were examined, it appears wind energy would be essentially cost neutral. We believe these conditions are realistic. But certainly many alternatives to these cases merit consideration. For instance, used wind generation equipment with installed costs below $\$ 500 \mathrm{per} \mathrm{kW}$ (half the price of new equipment) might lead to further savings. For example, the market currently offers 10 -year old $60 \mathrm{~kW}$ wind turbines for about $\$ 8000$, which may need an additional $\$ 8000$ for refurbishment and handling, plus installation and balance of station costs. Alternatively, larger wind turbines on tall towers might reap significant benefits from the strong positive vertical wind shears measured. It would be extremely helpful to measure wind speeds at $50 \mathrm{~m}$. If wind energy is considered beneficial for non-economic reasons in addition to the slight savings shown, much larger systems (and greater penetration) would be possible. Quantities of scale would tend to favor the economics of larger wind turbines and farms.

We have not tried to examine the relationship between wind energy and the grid demand costs. Large wind energy savings may do little to reduce demand costs, unless the wind shows consistency and strong correlation with demand loads. Although the concept of demand side management (DSM) may be overused, it could lead to significant savings in demand costs, and merits further study.

Different economic assumptions, such as higher and lower inflation, also can have significant impacts on such borderline results, and also should be examined further. Other factors that could impact the results include the actual capital and installation costs of the wind equipment and future TEP energy prices. 


\section{REFERENCES}

1. Olsen, T. and McKenna, E. (1996). Hybrid Energy System Cost Analysis: San Nicolas Island, California. NREL/TP-440-21120. Golden, CO: National Renewable Energy Laboratory.

2. McKenna, E. and Olsen, T. (1996). Wind Resource Assessment: San Nicolas Island, California. NREL/TP-442-20231. Golden, CO: National Renewable Energy Laboratory.

4. McKenna, E. (1993). Review of Initial Feasibility of Wind Energy for Fort Huachuca, Arizona - SERDP Project. Interoffice Memorandum. National Renewable Energy Laboratory.

5. Elliott, D.L. et al. (1987). Wind Energy Resource Atlas of the United States.

DOE/CH10093-4. Richland, WA: Pacific Northwest Laboratory.

6. Hunter, R., and Elliott, G. (1994). Wind Diesel Systems, Cambridge University Press.

7. NREL (1996). Request For Proposals: Product Improvement Project. No. RAT-6-16477. Golden, CO: National Renewable Energy Laboratory. 
APPENDIX: Economic Summary Tables 
Input Values

\section{Quantity}

System load, (kWh/y)

Grid energy (kWh/y)

Wind energy (kWh/y)

Diesel fuel usage, no wind (l/yr) $F L$

Diesel fuel usage, with wind (l/yr) $F$

Grid energy cost $(\$ / \mathrm{kWh}) \quad$ FC

System life, (yrs)

General inflation

Grid energy inflation

Discount rate

Interest

Term of loan, (yrs)

$\begin{array}{lr}\text { SL } & 107,634,800 \\ & 104,103,816 \\ \text { FL } & 3,530,984 \\ \text { FL } & \\ \text { FC } & 0.071 \\ \text { L } & 30 \\ \text { I } & 3.0 \% \\ \text { e } & 3.0 \% \\ \text { d } & 6.9 \% \\ \text { b } & 10.0 \% \\ \text { N } & 10\end{array}$

\section{Calculated Values for Both Systems}

Capital cost

Initial payment on system

Loan

Annual payment

NPV of annual payment

Grid energy cost per annum

NPV of energy costs

Overhaul cost per annum

NPV of overhaul costs

$O \& M$ costs per annum

NPV of O\&M costs

Total annual costs

Total system NPV, TNPV

Annual savings

Levelized cost of energy, COE

Payback period, years

Internal rate of return, IRR, $(x)$
8

\section{Economic Factors}

Present worth factor of fuel costs, PWFF, $a=(1+e) /(1+d)$ Present worth factor of $O \& M$ costs, PWFO, $a=(1+i) /(1+d)$ Present worth factor of interest payments, PWFP, $a=1 /(1+b)$

Capital recovery factor for system income, CRFI, $a=1 /(1+d)$

Capital recovery factor for interest payments, CRFP, $a=1 /(1+b)$

\begin{tabular}{|c|c|c|}
\hline a variable & nvariable & $Y(a, n)$ \\
\hline 0.96352 & 30 & 17.74945 \\
\hline 0.96352 & 30 & 17.74945 \\
\hline 0.93545 & 10 & 7.05616 \\
\hline a variable & n variable & $\underline{x(a, n)}$ \\
\hline 0.93545 & 30 & 0.07978 \\
\hline 0.90909 & 10 & 0.16275 \\
\hline
\end{tabular}

Grid Energy

Only

0
0
0
0
0

$7,642,071$

$135,642,573$

Afnpv $=$ Af $\bullet$ PWFF

Ao

Aonpv $=A Q$ * PWFO

Am

$A m n p v=A m * P W F O$

$A t=A p+A f+A o+A m$

$=A d+s u m(N P V s)$

$S v=d s \mid A t-h b d A t$

$=$ TNPV ${ }^{*} \mathrm{CAFI} / \mathrm{SL}$

$P=C / S$

$\left[(1+x)^{\wedge} L-1\right] /\left[x^{*}(1+x)^{\wedge} L\right]-P=$
Hybrid System
Grid Part

0
0

0

0

$7,391,371$

$131,192,788$

0

0

$7,391,371$

$131,192,788$

0.101

0.101
Hybrid System Wind Part

$2,888,800$

$2,888,800$

0

0

0

0

8,000

141,996

40,606

720,740

48,606

$3,751,536$

0.085

0.000
Hybrid System

Total

$2,888,800$

$2,888,800$

0
0
0

$7,391,371$

$131,192,788$

8,000

141,996

40,606

720,740

$7,439,977$

$134,944,323$

202,094

0.100

14.29

$5.7 \%$

(NPV = net present value; $I C C=$ initial capitol cost; $B O S=$ balance of station $=26 \% 1 C C ; O \& M=$ operations and maintenance)

$\begin{array}{lllll}6.4 & 0.096 & 0.100 & 16.70 & 4.3 \% \\ 7.0 & 0.085 & 0.100 & 14.29 & 5.7 \% \\ 7.7 & 0.076 & 0.100 & 12.48 & 6.9 \%\end{array}$

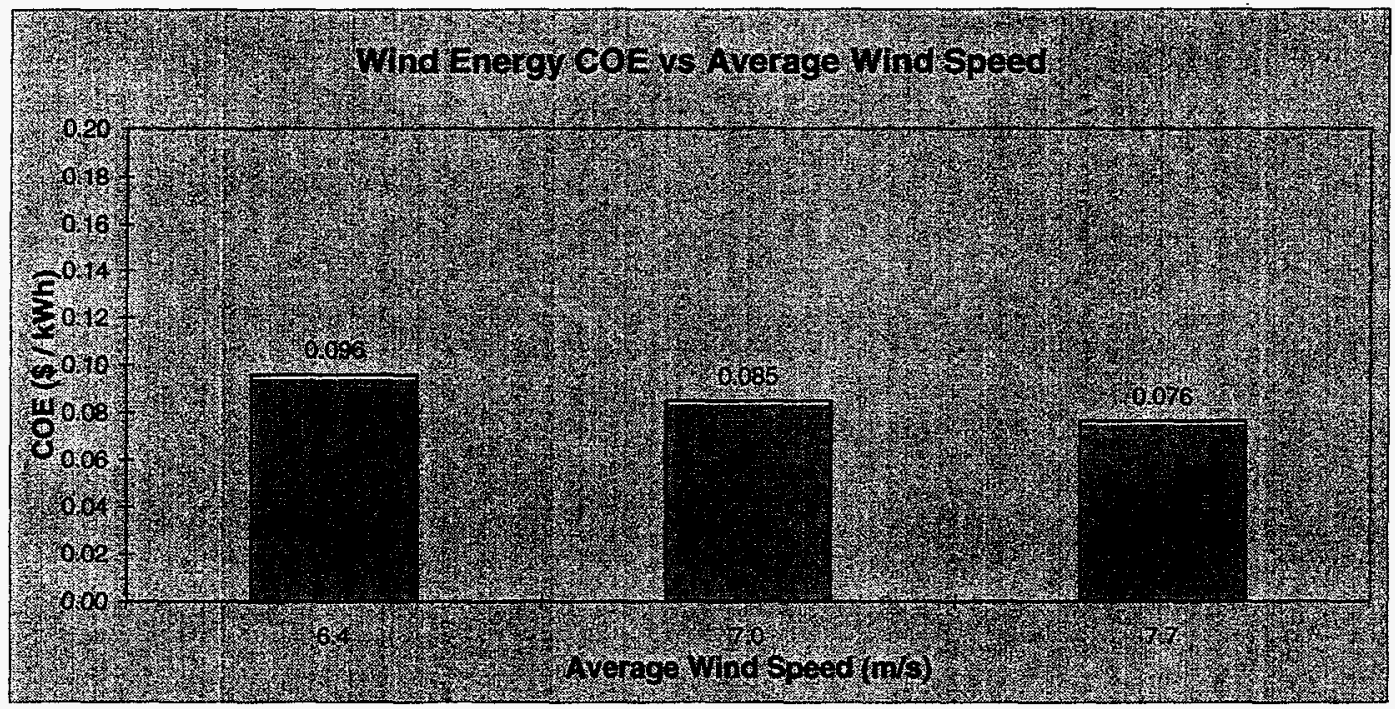



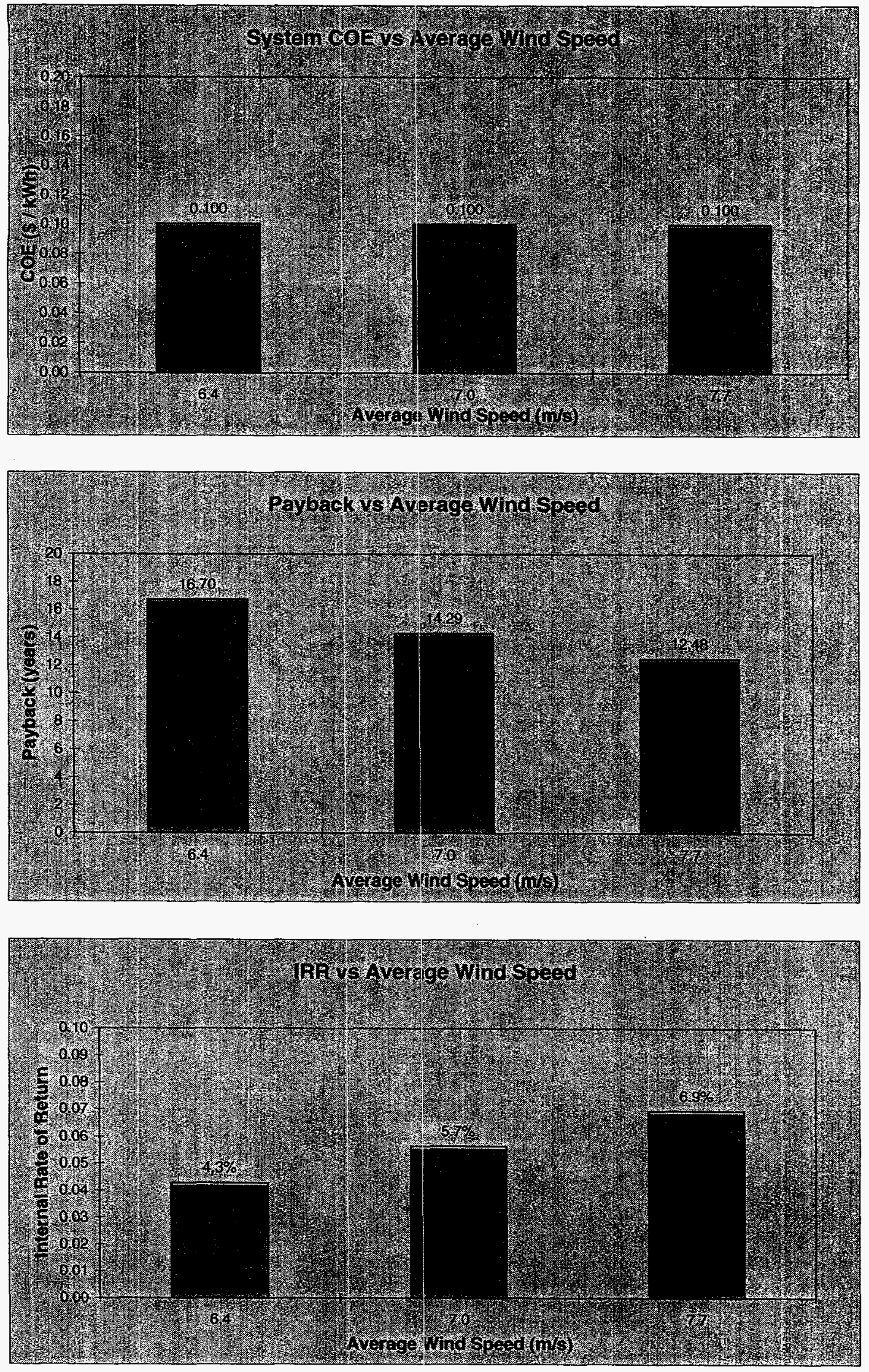

thecon $1 . x \mathrm{Is}, 11 / 14 / 97$ 


\section{Turbine:}

Quantity:

Input Values

System load, (kWh/y)

Grid energy ( $k W h / y)$

SL $\quad \begin{array}{r}107,634,800 \\ 104,592,474\end{array}$

Wind energy (kWhly)

Diesel fuel usage, no wind (Vyr) FL

Diesel fuel usage, with wind (l/yr) FL

Grid energy cost ( $\$ / \mathrm{kWh})$

FC

System life, (yrs)

General inflation

Grid energy inflation

Discount rate

Interest

Term of loan, (yrs)
L

d

b

N

\section{$225 \mathrm{~kW}$, Commercial}

$3,042,326$

0.071

30

$3.0 \%$

$3.0 \%$

$6.9 \%$

$10.0 \%$

10

\section{Economic Factors}

Present worth factor of fuel costs, PWFF, $a=(1+e) /(1+d)$ Present worth factor of O\&M costs, PWFO, $a=(1+i) /(1+d)$ Present worth factor of interest payments, PWFP, $a=1 /(1+b)$

Capital recovery factor for system income, $\mathrm{CRFI}, \mathrm{a}=1 /(1+\mathrm{d})$

Capital recovery factor for interest payments, CRFP, $a=1 /(1+b)$

$\begin{array}{rrr}\text { a variable } & \text { nvariable } & \underline{Y(a, n)} \\ 0.96352 & 30 & 17.74945 \\ 0.96352 & 30 & 17.74945 \\ 0.93545 & 10 & 7.05616 \\ \underline{\text { a variable }} & \underline{\text { nvariable }} & \underline{X(a, n)}\end{array}$

$\begin{array}{lll}0.93545 & 30 & 0.07978 \\ 0.90909 & 10 & 0.16275\end{array}$

\section{Calculated Values for Both Systems}

\section{Capital cost}

Initial payment on system

Loan

Annual payment

NPV of annual payment

Grid energy cost per annum

NPV of energy costs

Overhaul cost per annum

NPV of overhaul costs

O\&M costs per annum

NPV of O\&M costs

Total annual costs

Total system NPV, TNPV

Annual savings

Levelized cost of energy, COE

Payback period, years

Internal rate of return, IRR, (x)
$C=1 C C+B O S$

Ad

$A l=C-A d$

$A p=A l^{*}$ CRFP

$A p n p v=A{ }^{*} P W F P$

$A f=F L \cdot F C$

Afnpv $=$ Af ${ }^{\bullet}$ PWFF

Ao

Aonpv $=$ Ao $\bullet$ PWFO

Am

$A m n p v=A m^{*} P W F O$

$A t=A p+A f+A o+A m$

$=$ Ad+sum(NPVs)

$\mathrm{Sv}=\mathrm{ds} \mid \mathrm{At} \cdot \mathrm{hbd}$ At

$=$ TNPV ${ }^{*} \mathrm{CRFI} / \mathrm{SL}$

$P=C / S V$

$\left[(1+x)^{\wedge} L-1\right]\left[x^{*}(1+x)^{\wedge} L\right]-P=$
Grid Energy

Only

0

0

0
0

0

0

$7,642,071$

$135,642,573$

0

0
0

0

$7,642,071$

$135,642,573$

0.101
Hybrid System

Grid Part

0

0

0

0

$7,426,066$

$131,808,600$

0

0

0

$7,426,066$

$131,808,600$

0.101
Hybrid System Wind Part

$2,888,800$

$2,888,800$

0

0

0

0

8,000

141,996

34,987

620,996

42,987

$3,651,791$

0.096
Hybrid System

Total

$2,888,800$

$2,888,800$

0
0

$7,426,066$

$131,808,600$

8,000

141,996

34,987

620,996

$7,469,052$

$135,460,391$

173,018

0.100

16.70

$4.3 \%$

(NPV = net present value; ICC $=$ initial capitol cost; $B O S=$ balance of station $=26 \% I C C ; O \& M=$ operations and maintenance) 


\section{Input Values}

System load, (kWh/y) Grid energy (kWh/y)

Wind energy ( $\mathrm{kWh} / \mathrm{y})$

Diesel fuel usage, no wind $(1 / y r) \quad F L$

Diesel fuel usage, with wind (I/yr) $F L$

Grid energy cost (\$/kWh) FC

System life, (yrs)

General inflation

Grid energy inflation

Discount rate

Interest

Term of loan, (yrs)

SL

$$
\begin{array}{r}
107,634,800 \\
103,609,9159 \\
4,024,8: 31
\end{array}
$$

0.071

30

$3.0 \%$

$3.0 \%$

$6.9 \%$

$10.0 \%$

10

\section{Economic Factors}

Present worth factor of fuel costs, PWFF, $a=(1+e) /(1+d)$

Present worth factor of O\&M

costs, PWFO, $a=(1+i) /(1+d)$

Present worth factor of interest

payments, PWFP, $a=1 /(1+b)$

Capital recovery factor for system income, CRFI, $a=1 /(1+d)$

Capital recovery factor for interest payments, CRFP, $a=1 /(1+b)$

\begin{tabular}{crc} 
a variable & nvariable & \multicolumn{1}{l}{$Y(a, n)$} \\
0.96352 & 30 & 17.74945 \\
0.96352 & 30 & 17.74945 \\
0.93545 & 10 & 7.05616 \\
a variable & $\underline{\text { nvariable }}$ & $\underline{X(a, n)}$ \\
0.93545 & 30 & 0.07978 \\
0.90909 & 10 & 0.16275
\end{tabular}

\section{Calculated Values for Both Systems}

\section{Capital cost}

Initial payment on system

Loan

Annual payment

NPV of annual payment

Grid energy cost per annum

NPV of energy costs

Overhaul cost per annum

NPV of overhaul costs

O\&M costs per annum

NPV of O\&M costs

Total annual costs

Total system NPV, TNPV

Annual savings

Levelized cost of energy, COE

Payback period, years

Internal rate of return, IRR, (x)
$C=1 C C+B O S$

Ad

$\mathrm{Al}=\mathrm{C}-\mathrm{Ad}$

$A p=A l^{*}$ CRFP

$A p n p v=A P * P W F P$

$A f=F L * F C$

Afnpv $=$ Af $*$ PWFF

Ao

$A o n p v=A O * P W F O$

Am

Amnpv $=A m * P W F O$

$A t=A p+A f+A 0+A m$

$=A d+$ sum (NPVs)

Sv $=d s l$ At - hbd At

$=$ TNPV*CRFI/SL

$P=C / S v$

$\left.\left[(1+x)^{\wedge} L-1\right] / x^{*}(1+x)^{\wedge} L\right]-F^{\prime}=$
Grid Energy

Only

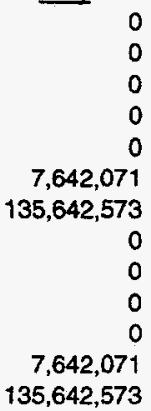

0.101

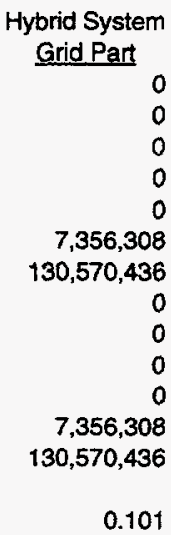

0.000
Hybrid System

Total

$2,888,800$

$2,888,800$

Wind Part

$2,888,800$

0

0

0

8,000

141,996

46,286

821,543

54,286

$3,852,339$

0.076

141,996

46,286

821,543

$7,410,593$

$134,422,775$

231,477

0.100

12.48

$6.9 \%$

(NPV = net present value; $I C C=$ initial capitol cost; $B O S=$ balance of station $=26 \% \mathrm{ICC} ; O \& M=$ operations and maintenance) 


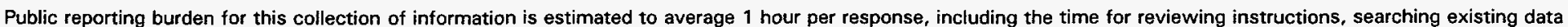

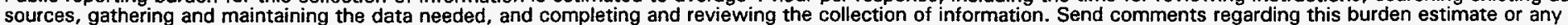

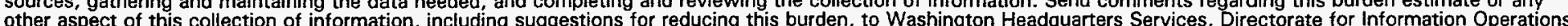

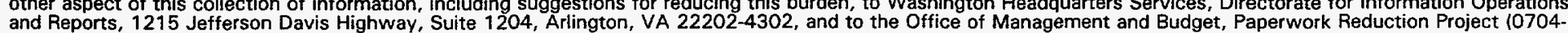
and Reports, 1215 Jefferson Davi
0188 ). Washington, DC 20503

\begin{tabular}{|l|l|l}
\hline 1. & $\begin{array}{l}\text { 2. } \\
\text { REPORT DATE } \\
\text { December } 1997\end{array}$ & $\begin{array}{l}\text { 3. REPORT TYPE AND DATES COVERED } \\
\text { Subcontractor Report }\end{array}$
\end{tabular}

4. TITLE AND SUBTITLE

Wind Resource Assessment and Wind Energy System Cost Analysis:

Fort Huachuca, Arizona

6. $A U T H O R(S)$

Timothy L. Olsen, Ed McKenna

7. PERFORMING ORGANIZATION NAME(S) AND ADDRESS(ES)

R. Lynette \& Associates

425 Pontius Ave., North Suite 150

Seattle, Washington 98109

\section{SPONSORING/MONITORING AGENCY NAME(S) AND ADDRESS(ES)}

National Renewable Energy Laboratory

1617 Cole Blvd.

Golden, CO 80401-3393
5. FUNDING NUMBERS

C: CAK-6-15387-01

TA: WE802120
8. PERFORMING ORGANIZATION REPORT NUMBER

\section{SUPPLEMENTARY NOTES}

NREL Technical Monitor: Ed McKenna

12a. DISTRIBUTION/AVAILABILITY STATEMENT National Technical Information Service

U.S. Department of Commerce

5285 Port Royal Road

Springfield, VA 22161 12b. DISTRIBUTION CODE

UC- 1210

\section{ABSTRACT (Maximum 200 words}

The objective of this joint DOE and National Renewable Energy Laboratory (NREL) Strategic Environmental Research and Development Program (SERDP) project is to determine whether wind turbines can reduce costs by providing power to U.S. military facilities in high wind areas. In support of this objective, one year of data on the wind resources at several Fort Huachuca sites was collected. The wind resource data were analyzed and used as input to an economic study for a wind energy installation at Fort Huachuca. The results of this wind energy feasibility study are presented in the report.

\begin{tabular}{|c|c|c|c|c|c|c|c|}
\hline \multirow[t]{2}{*}{14.} & & 15. & NUMBER OF PAGES \\
\hline & \multicolumn{5}{|c|}{$\begin{array}{l}\text { SUBJECT TERMS } \\
\text { renewable energy; wind energy; wind resource assessment; wind turbines-electricity } \\
\text { generation; wind energy system cost analysis; wind energy and military applications; } \\
\text { Fort Huachuca; wind energy, Arizona; wind energy, economics }\end{array}$} & 16. & PRICE CODE \\
\hline 17. & $\begin{array}{l}\text { SECURITY } \\
\text { CLASSIFICATION } \\
\text { OF REPORT } \\
\text { Unclassified } \\
\end{array}$ & 18. & $\begin{array}{l}\text { SECURITY } \\
\text { CLASSIFICATION } \\
\text { OF THIS PAGE } \\
\text { Unclassified }\end{array}$ & 19. & $\begin{array}{l}\text { SECURITY } \\
\text { CLASSIFICATION } \\
\text { OF ABSTRACT } \\
\text { Unclassified } \\
\end{array}$ & 20. & $\begin{array}{l}\text { LIMITATION OF ABSTRACT } \\
\text { UL }\end{array}$ \\
\hline
\end{tabular}

